\title{
Advanced Turbine Systems Program Conceptual Design and Product Development Task 8.1 -- Low-Pressure Drop Recuperator
}

\section{Topical Report}

September 1995

Work Performed Under Contract No.: DE-AC21-93MC30246

For

U.S. Department of Energy

Office of Fossil Energy

Morgantown Energy Technology Center

Morgantown, West Virginia

By

Solar Turbines

San Diego, California 


\section{DISCLAIMER}

This report was prepared as an account of work sponsored by an agency of the United States Government. Neither the United States Government nor any agency thereof, nor any of their employees, makes any warranty, express or implied, or assumes any legal liability or responsibility for the accuracy, completeness, or usefulness of any information, apparatus, product, or process disclosed, or represents that its use would not infringe privately owned rights. Reference herein to any specific commercial product, process, or service by trade name, trademark, manufacturer, or otherwise does not necessarily constitute or imply its endorsement, recommendation, or favoring by the United States Government or any agency thereof. The views and opinions of authors expressed herein do not necessarily state or reflect those of the United States Government or any agency thereof.

This report has been reproduced directly from the best available copy.

Available to DOE and DOE contractors from the Office of Scientific and Technical Information, 175 Oak Ridge Turnpike, Oak Ridge, TN 37831; prices available at (615) 576-8401.

Available to the public from the National Technical Information Service, U.S. Department of Commerce, 5285 Port Royal Road, Springfield, VA 22161; phone orders accepted at (703) 487-4650. 


\title{
Advanced Turbine Systems Program Conceptual Design and Product Development Task 8.1 -- Low-Pressure Drop Recuperator
}

\author{
Topical Report
}

Work Performed Under Contract No.: DE-AC21-93MC30246

\author{
For \\ U.S. Department of Energy \\ Office of Fossil Energy \\ Morgantown Energy Technology Center \\ P.O. Box 880 \\ Morgantown, West Virginia 26507-0880 \\ By \\ Solar Turbines \\ 9330 Sky Park Court \\ San Diego, California 92123
}

September 1995 


\section{CONTENTS}

Paragraph

3.1 Primary Surface Recuperator

3.2 Life Considerations

3.3 Program

3.4 2-Dimensional Analytical Model

4.1 Transient Test Rig

4.2 Performance Test Rig

4.3 Flattened Tube Test

5.1 Performance Test, Background

5.2 Test Points

5.3 Manufacturing Tolerances

6.1 Transient Test

6.2 Performance Test

6.3 Flattened Tube Test

7.1 Transient Test

8.1 Transient Test 


\section{LIST OF FIGURES}

Fiqure

Page

1

Primary Surface Sheets

4

2

PSR Air Cell

4

Core Assemblies $\quad 5$

4

Thermally Balanced Restraint System

Air and Exhaust Gas Ducting

$\begin{array}{ll}\text { High Capacity Air Cell } & 7\end{array}$

$\begin{array}{ll}\text { C-Flow Configuration } & 7\end{array}$

8

$\begin{array}{ll}\text { Z-Flow Configuration } & 7\end{array}$

Transient Test Rig

Steady-State Test Rig $\quad 9$

11

Gas-Out Mixer

Test Core

Effect of Flow Rate and Power Level on Thermal Effectiveness

Effect of Flow Rate and Power Level on Air-Side Pressure Drop

Effect of Flow Rate and Power Level on Gas-Side Pressure Drop

Thermal Attenuator Test

Thermal Attenuator Test

Comparison Between Predicted and Measured Thermal Effectiveness

Comparison Between Predicted and Measured Air-Side Pressure Drop

Comparison Between Predicted and Measured Gas-Side Pressure Drop 


\section{TABLES}

Table

Page

Operating Temperature and Pressures of the Benchmark Test Core

2

Gas and Air Flow Rate Conditions of the Benchmark Test Core

12

3

Thermal Attenuation

16

Transient Performance Data for Heat Transfer Surface \#90 (Gas-Side)

Transient Performance Data for Heat Transfer Surface \#91 (Air-Side)

Transient Performance Data for Heat Transfer Surface \#92 (Combined) 


\section{EXECUTIVE SUMMARY}

The strategy of the Advanced Turbines Systems (ATS) program is to develop a new baseline for industrial gas turbine systems for the 21st century, me日ting the buying criteria of industrial gas turbine end users and having growth potential as a product line. These criteria resulted in the selection of a recuperated gas turbine cycle. The eventual engine or engines that result will utilize Solar's Primary Surface Recuperator technology (PSR).

Solar's -Primary Surface Recuperator (PSR) technology is based on 24 years of development and operational experience. This technology has typically been applied to relatively low pressure drop cycles having modest exhaust gas temperatures. One objective of the ATS program is to develop engines of much higher thermal efficiency resulting in engines that fire hotter and have higher exhaust gas temperatures. Other goals included lower emission, cost of power and improved RAMD. Recuperator life prediction, creep modeling and performance prediction become even more important factors in the design.

Performance has been predicted using an in-house analytical model of the PSR. The accuracy of predictions has been notably good at design point. However, with an engine like ATS where high efficiency is such a salient and vital feature, predictions must be of the utmost accuracy, especially over the broad operating range of the turbine. An influencing factor of these predictions is the validity of the empirical data the model uses. Performance data have been obtained for the candidate heat transfer surface. Furthermore, performance data were obtained on a scaled rig to provide the necessary data to validate and calibrate the analytical model. The pretest predictions of air-side and gas-side pressure drop were in very good agreement with the actual test results. The predicted effectiveness also agreed well with that actually determined by experiment.

A flattened tube test was designed to determine dimensional changes of the PSR heat transfer surface profile after exposure. These data are to be used in the finite element creep modeling that is underway. The test was still in progress at the time this report was written. Data will be reported separately upon conclusion of the test. 


\subsection{INTRODUCTION}

Solar Turbines has embarked on an advanced turbine systems program to design and commercialize a high cycle efficiency, low exhaust emissions gas turbine engine. The system will incorporate a recuperator to significantly increase cycle efficiencies. Solar's Primary Surface Recuperator (PSR) technology, grounded on 24 years of development and operational experience, will be utilized in this ATS program. The successful commercialization of the PSR technology is evident in Solar's own engines as well as retrofits of other manufacturer's engines, such as the General Electric Frame 3. The ATS application promises to be technologically challenging for the recuperator as the higher firing temperatures will result in a higher exhaust gas inlet temperature for the recuperator. Therefore, much of the recuperator development focus is on refining design methodology so that predictions can be made with even greater accuracy as performance is most definitely an issue. 


\subsection{PURPOSE}

The ATS goals are ambitious. A high cycle efficiency is the keystone of the system, thus accurate performance prediction tools are vital to attain this goal inexpensively and with confidence. Solar's 2D analytical recuperator performance model has been invaluable in developing recuperators for various applications. It has been very effective in predicting design point performance but not as effective over a broad operating range. Where performance is paramount, however, as it is with ATS, the level of accuracy that is needed over a broad operating range in predictive methods also becomes paramount. The ATS application utilizes an advanced primary surface air cell for which much empirical data are lacking. Therefore, the focus in these Phase II tests is to acquire the experimental data that are required to validate and/or calibrate the analytical model. These data take the form of pressure and temperature measurements which are reduced to friction factor and Colburn modulus data (" $f$ and $j$ ). Steady-state performance data (pressure, differential pressure and temperature measurements across the recuperator) are also needed for validation and calibration of the model..

Yet another goal of ATS is reduced life cycle cost. For the recuperator, there are a number of parameters involved in an optimization of life cycle cost. These include material choice, foil thickness and life. The proper combination of factors can only be selected when adequate data exist on the life of various potential recuperator materials. Solar has extensive material development programs in progress to generate some of the required information. The flattened tube test, described briefly in this report, is an ongoing test to provide detailed data on the behavior of the primary surface under high temperature and pressure conditions. Since this test is still in progress, results of the test will be reported as an addendum once the test has concluded. 


\subsection{BACKGROUND}

\subsection{PRIMARY SURFACE RECUPERATOR}

Solar's PSR technology is grounded in over two decades of development work that began at Caterpillar in the 1960s. The original intent of this work was to develop recuperators for vehicular gas turbine applications. This was extended to include stationary gas turbines with Caterpillar's introduction of the 5650 gas turbine. That basic technology for the recuperated 5650 is still with us. Solar has improved on it in a significant way since 1981 and will fine tune the design even further with the development of a recuperator to ATS.

The PSR is made of thin, typically 0.003-inch type 347 stainless steel folded into a corrugated pattem. This pattem, shown in Figure 1, maximizes the primary surface area that is in direct contact with exhaust gas on one side and compressor discharge air on the other. Pairs of these sheets are welded together around the perimeter to form air cells (Figure 2), the basic building block of the PSR. Each cell is pressure checked before it is welded into the recuperator core assembly, as shown in Figure 3. There are no internal welds or joints within the air cell.

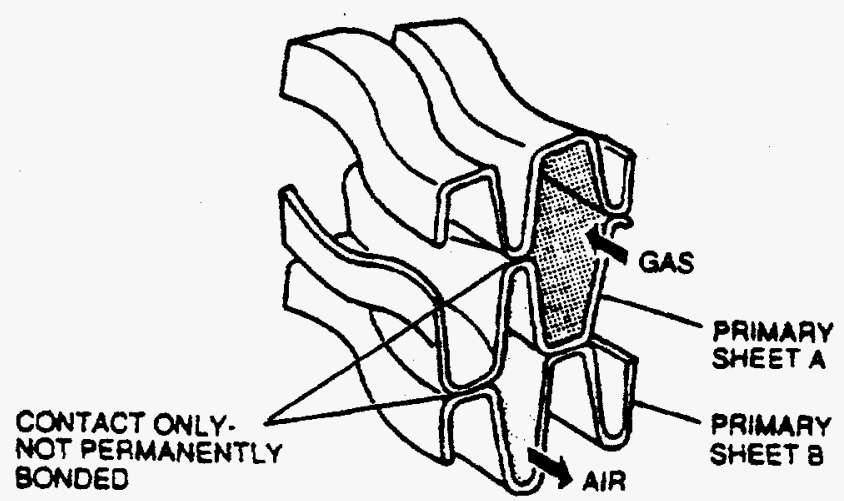

Figure 1. Primary Surface Sheote

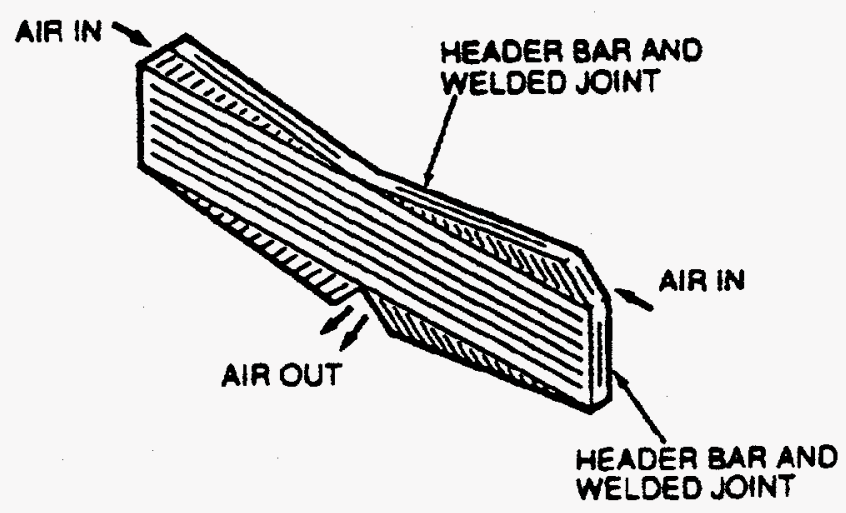

Figure 2. PSR Air Cell
Once the completed recuperator core has been pressure checked, a thermally balanced restraint system (TBRS) is added to the core to contain the pressure forces. This is seen in Figure 4. The individual air cells consist of the thin folded sheets welded to header bars located at the air cell edge. The header bars are designed to resist internal pressure without support, but the primary sheets require full support to prevent "ballooning" under internal pressure.

The necessary support is provided by simply clamping the recuperator core between two rigid plates referred to as end beams which cover the ends of the core. The clamping force is provided by preloaded tie rods that connect the two end beams. The tie rods are specifically designed to have thermal expansion characteristics which closely match those of the core, so that constant support is provided during thermal transients. To enhance thermal response, the tie rods are located in the gas stream, and each rod assembly consists of a bundle of small diameter rods across which exhaust gas can flow. 


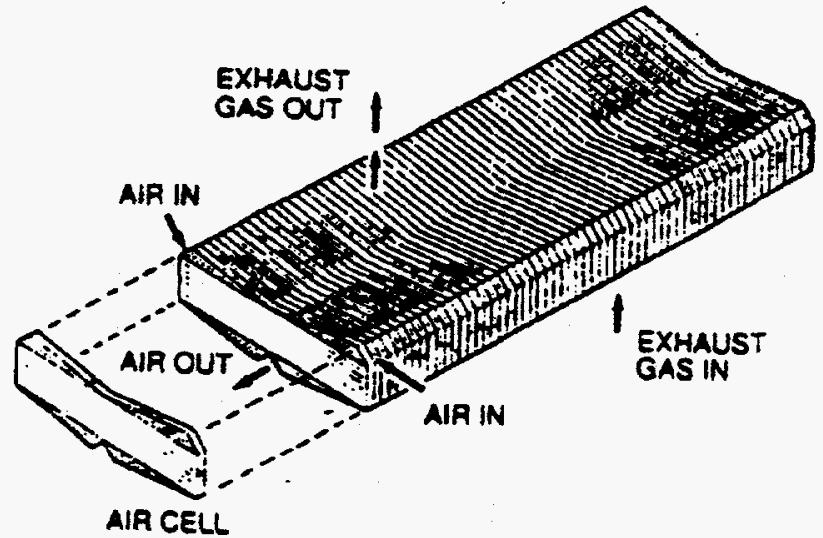

Figure 3. Core Assemblies

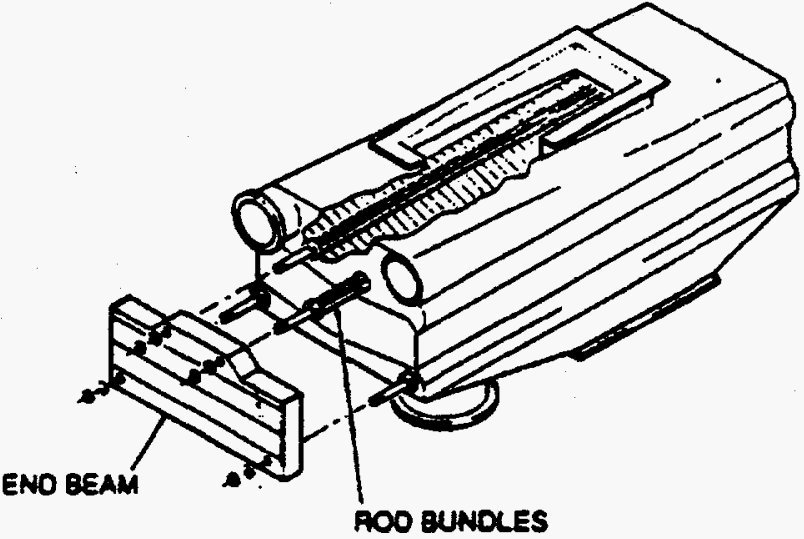

Figure 4. Thermally Balanced Restraint System

This extemal restraint philosophy has two major advantages. First, it eliminates the need for internal structures within air cells and the recuperator core which would otherwise be required to hold the core together. Such bracing would increase core volume and create internal thermal stresses due to differential heating rates of the thin sheet metal and heavier structural elements.

Secondly, the extemal restraint relieves the recuperator air and exhaust ducting of any requirement to provide structural support. This sheet metal ducting is added to the recuperator core, as required, to direct the air and exhaust gases through the recuperator assembly (Figure 5). Use of thin duct walls enhance the flexibility of the core and its ability to accommodate the natural curvature imposed upon the core by its internal temperature differential without high stresses.

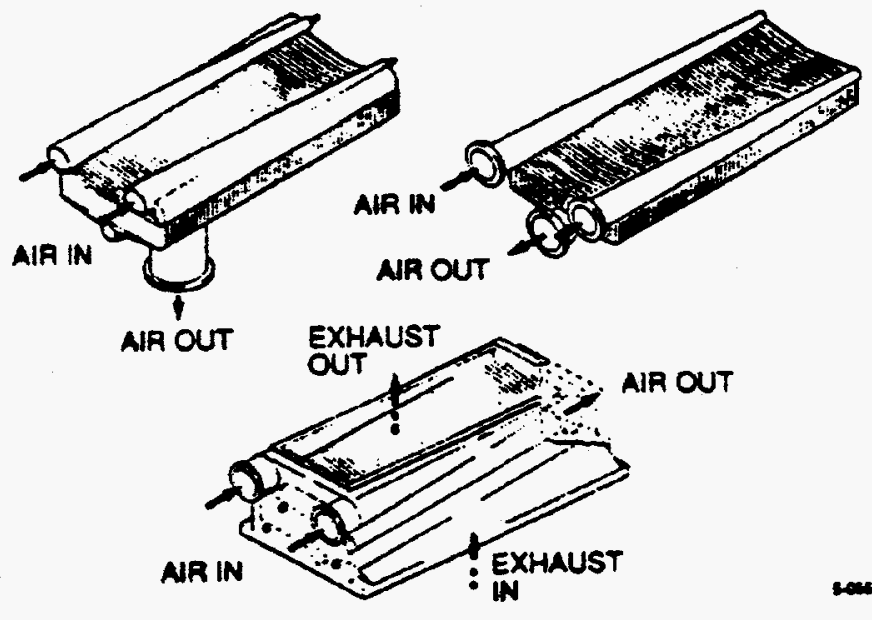

Figure 5. Air and Exhaust Gas Ducting

The recuperator assembly is mounted to the gas turbine in a manner essentially free of external loads due to piping reactions and thermal expansion. Piping reaction forces are absorbed by a pressure-balanced bellows assembly at the air inlet and pinned centerline mount on the hot air discharge nozzle. The other recuperator structural support is a set of pinned swing links attached to the rear end beam. When the core expands thermally relative to its support structure, the mounts rotate to accommodate the increasing length and the natural curvature without imposing loads back onto the recuperator core.

These features allow the recuperator to be easily and directly integrated with the turbine to obtain a very compact package.

\subsection{UIFE CONSIDERATIONS}

Most recuperators fail as a result of a combination of thermal and pressure-induced mechanical cycling. Environmental influences, such as corrosion and oxidation, accelerate recuperator failure. 
The PSR is designed to substantially reduce all of these effects, be very reliable and require low maintenance.

When balanced against cost, the proper choice of materials, that are designed to overcome the variety of environments gives the recuperator the ability to endure severe environments found in both natural gas and liquid fueled gas turbines. The PSR design does not tie the structure with multiple interconnection points, but allows the individual components that make up an air cell and the air cells that makeup the overall recuperator core structure to absorb strain. These features give the PSR the ability to accommodate large thermal gradients under operating conditions. With the thermal stresses substantially reduced, the PSA structure can more easily handle the pressure forces.

Oxidation and corrosion resistance are important criteria to consider when selecting a material for PSR applications as the material's environmental resistance determines the long term durability of the recuperator. With the very thin materials used, a stable oxide film must be maintained to avoid excessive material loss.

For the majority of gas turbines operating at temperatures lower than $650^{\circ} \mathrm{C}\left(1200^{\circ} \mathrm{F}\right)$, type 347 stainless steel $(18 \% \mathrm{Cr} / 10 \% \mathrm{Ni} / 1 \% \mathrm{Cb})$ provides excellent oxidation resistance. Its outstanding performance in this temperature range is derived from the presence of a thin, adherent $\mathrm{Cr}_{2} \mathrm{O}_{3}$ oxide film which forms in service at a predictable rate. This surface film inhibits further transport of oxygen to the underlying material, thus avoiding excessive oxidation damage. At $700^{\circ} \mathrm{C}\left(1292^{\circ} \mathrm{F}\right)$, film instabilities and cracking may occur which could breach the protective layer and lead to accelerated oxidation.

Other recuperator materials have been qualified for higher temperature and pressure cycles. These include Inconel 625 and Haynes 230. Both of these materials possess outstanding properties as recuperator materials. However where cost is an issue, and it almost always is, these materials are less desirable. Additional material studies are in progress to identify alternate low cost materials for potential recuperated cycles. These investigations include yield, creep and oxidation tests.

\subsection{PROGRAM}

The ATS application is a challenging one, but quite doable within the program schedule and plan. There are two major areas of focus, namely, prediction and attainment of material life and performance. Three separate studies have been performed that address both of these areas. In the area of performance prediction and attainment is the heat transfer surface characterization and the performance test. For life prediction, is the so-called flattened tube test. This last test is still in progress and final result of this test will be reported on as a revision to this report.

The recuperator for ATS will utilize the so-called high capacity air cell, shown in Figure 6. This recent development at Solar is a significant improvement over the standard 5650 air cell. Scrap material is reduced which results in a significant material cost savings. There has been a deficiency of empirical data for this air cell. Heat transfer surface performance data are empirical data needed to support the design of a recuperator. Initial designs for ATS have used old $\mathbf{5 6 5 0}$ air cell data to support the new air cell design. The $\mathbf{5 6 5 0}$ surface is geometrically similar to the high capacity air cell, so in the absence of surface performance data for the new cell, it is an acceptable substitute. However, for performance predictions to be of the utmost accuracy, surface performance data for the high capacity cell is required. Furthermore, supporting data are also required to calibrate and validate the design methods. For this reason, a performance test was run using the new air cell design. 


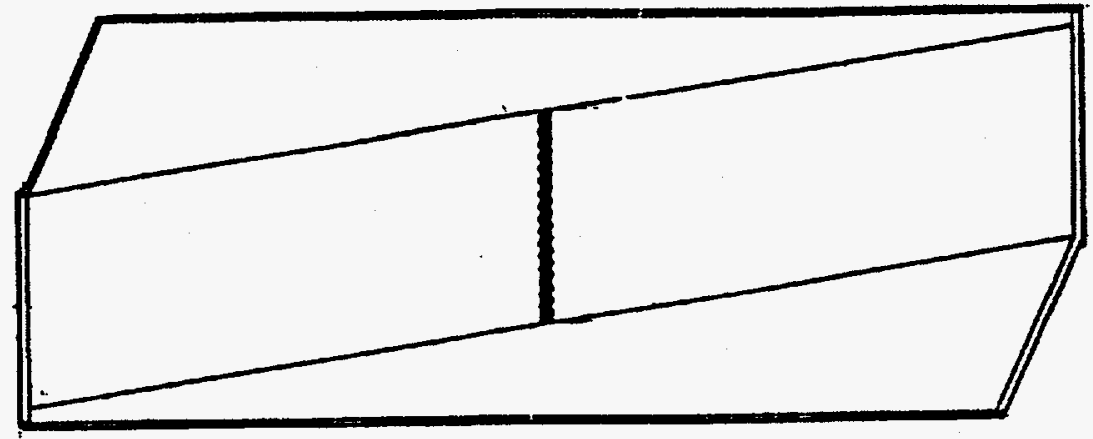

Figure 6. High Capacity Air Cell

\subsection{2-DIMENSIONAL ANALYTICAL MODEL}

Solar utilizes a variety of tools in designing a recuperator. One of the analytical tools developed inhouse over the years is the two-dimensional (2D) analytical model which provides a basis for the aerothermal design, analysis, and prediction of performance of the primary surface recuperator. This analytical method is an integrated finite element heat transfer and fluid flow model for the corrugated counterflow core as well as the inlet and outlet oblique cross flow triangular headers. The method enables one to establish the flow distribution across the core and triangular headers and quantify the flow, temperature, static pressure, and mass velocity fields in the core, triangular headers, and the transition region between the two.

The method is applicable to a broad type of recuperator design configurations, including the C-flow (Figure 7) and Z-flow (Figure 8) recuperators with rectangular, axisymmetric, or involute core configurations having crushed or welded header design.

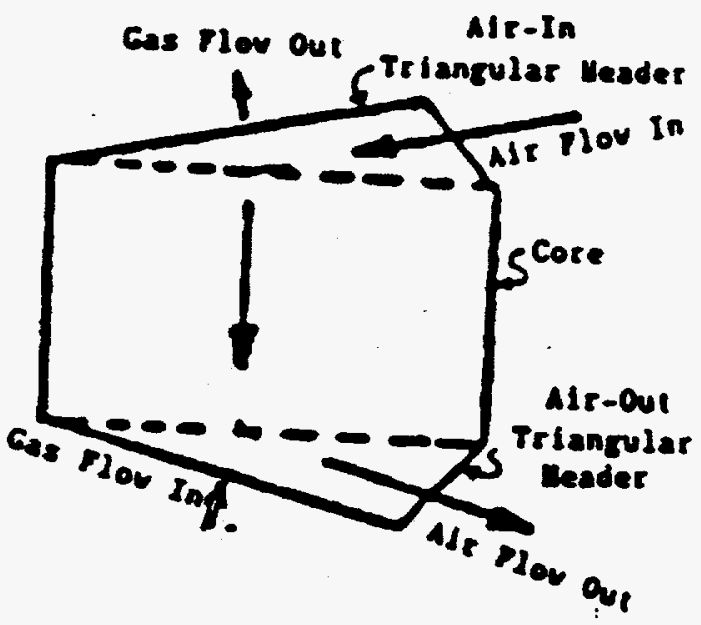

Figure 7. C-Flow Configuration

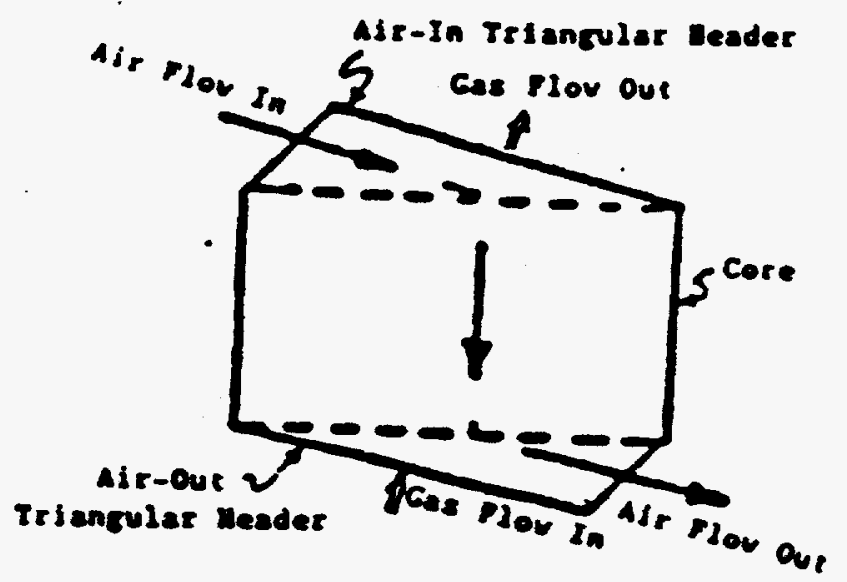

Figure 8. Z-Flow Configuration

The method was validated using limited empirical data on the 5650-class primary surface recuperators. A comparison between test results and pretest analytical prediction of effectiveness and pressure drop on the air- and gas-sides of the recuperator is provided later in this section to illustrate how accurately the performance of the primary surface recuperator can be predicted. 


\subsection{EXPERIMENTAL TEST FACILITIES}

Three preexisting test rigs have been used during the contract period to acquire data to assist the design of a recuperator for the ATS engine. Each of these rigs are described below.

\subsection{TRANSIENT TEST RIG}

The transient test rig, shown in Figure 9, is used to measure the performance characteristics of heat transfer surfaces based on a transient single blow test technique developed at Stanford University. Pressure and temperatures of the air entering and exiting the rig are measured over a broad range of Reynolds numbers and are then correlated and used as a basis for establishing the convective conductance on the air- and gas-sides of the recuperator.

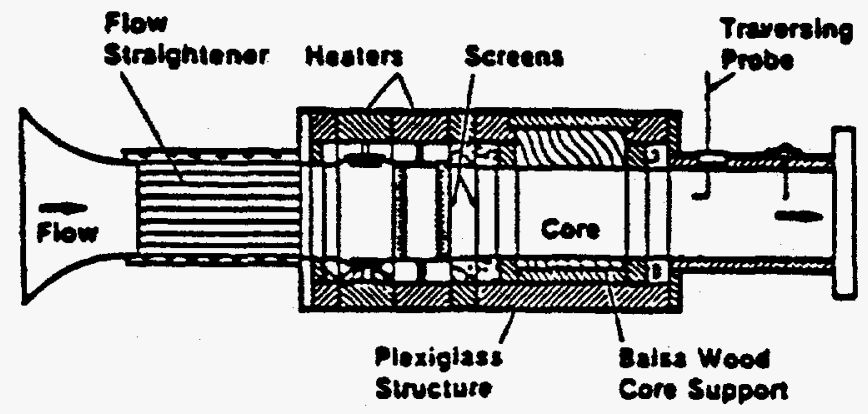

Figure 9. Transient Test Rig

Air is drawn into the transient rig from the surroundings into a bellmouth inlet section to provide a uniform flow stream into the heater. This air is heated and then flowed through the core sample. An orifice meter downstream of the test section is used to measure the air flow rate passing through the core. A valve situated downstream of the orifice meter controls the air flow rate passing through the core. An induced flow blower, located at the downstream side of the test rig, sustains a steady uniform flow of air through the test section.

Initially the rig is operated in steady-state mode. It is then subjected to a step change in the air temperature. The bellmouth and the flow straightener serve to straighten out the flow at the inlet of the heaters. Pressure and differential pressure measurements in inches of water are determined. All temperatures in the rig are measured using copper-constantan thermocouples. The time/ temperature history of the airflow stream at the core exit is recorded on a strip chart recorder. This same recorder is used to record the air temperature during the initial steady-state phase of the test.

Further rig modifications were performed as an effort to increase the precision of the rig, which has been accepted over the years to be around 12 percent. One source of error which has been identified is minute temperature aberrations in the ambient room air. These variations can be damped out considerably by adding a thermal attenuator, which is a device that provides some additional air mixing, thus damping out thermal gradients. Such a device was added to the rig and a series of tests were run to assess its performance.

This transient test rig is similar in design to the rig developed by Professor London at Stanford University. This rig has been used to study over 70 separate cores during the development of the optimum manufacturable heat transfer surface for the primary surface recuperator. Two previously run surfaces, denoted as surfaces $\# 19$ and $\# 52$, have become standard surfaces to ensure the measured data from the rig is consistent with data taken during previous tests. Each new surface characterization test includes a test of one or both of these standard surfaces. 


\subsection{PERFORMANCE TEST RIG}

The Performance Test Rig, also known as the steady-state rig, was designed to accurately measure the performance of an actual recuperator core under a broad range of typical engine conditions. A schematic of this rig is shown in Figure 10. In a sense, this rig is a scaled down recuperator simulator rig. Pressure loss and thermal effectiveness measurements are determined from tests on this rig. This data is invaluable as it demonstrates how well a given design can be expected to perform under various conditions. The data from it are useful in validating and calibrating the 2D analytical model, an in-house tool used for the design, analysis and prediction of performance of PSRs.

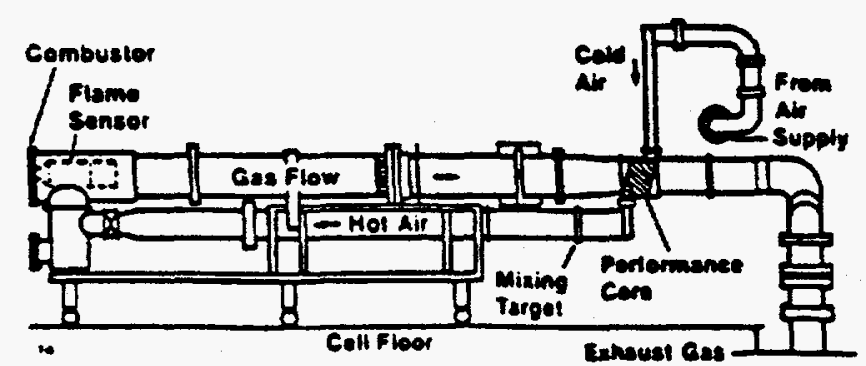

Figure 10. Steady-State Test Rig

High pressure air is supplied to the recuperator at a specified flow rate. The rig is instrumented to measure the performance of the recuperator with a high degree of accuracy. Test data, collected using a computerized data acquisition system, is analyzed online and compared to the original pretest predictions included as part of a test plan. Any larger-than-expected deviations are studied carefully to establish the cause.

Air is delivered from a constant pressure supply and enters the recuperator through a rectangular duct. Heat is exchanged with the hot gas inside the core and triangular headers. Hot gas generated in a combustor, enters the rig in crossflow. The air temperature increases as a result of heat transfer in the recuperator and the gas temperature drops.

The air is recirculated in the rig. The hot air leaving the recuperator is throttled down before entering the combustor. Natural gas, used to fuel the rig, is burned in the combustor and flows from there into the gas-side of the recuperator. The natural gas flow rate is small compared to the gas flow rate. The air and gas flow rates are approximately equal and can be changed independently to simulate the actual engine conditions.

A number of rig modifications were performed prior to any testing. Reducing the energy balance deviation was of prime concern. Additional rig insulation was used, additional thermocouples were added to the various temperature measurement planes and a gas out mixer was added to ensure temperature anomalies were damped out. A schematic of the gas-out mixer is shown in Figure 11. These rig modifications were quite effective. The energy balance

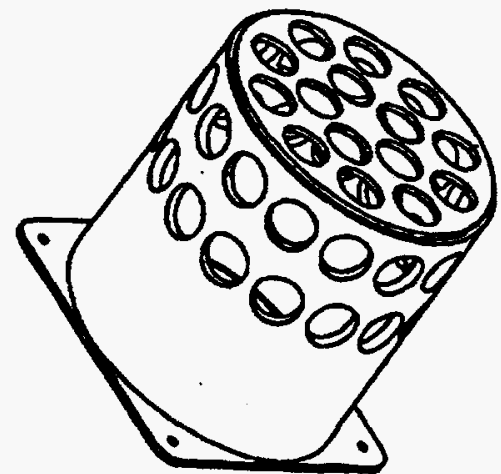

Figure 11. Gas-Out Mixer deviation was reduced to below three percent for the majority of test conditions.

\subsection{FLATTENED TUBE TEST}

The flattened tube test was designed to provide strain data that are needed to characterize the deformation of the recuperator's primary surface folded fin under a high temperature and pressurized environment. The results of this study are intended to validate a finite element model used for static and creep analysis of the primary surface. The dimensions of the flattened tube, which is geometrically similar to the primary surface, are measured periodically to determine the deformation of the profile as a function 
of time. This test, still in progress, will continue until the tube fails. At the time of the writing of this report, the primary tube had deformed but had not yet failed.

Two thermocouples were attached on the test specimen to monitor temperatures during the test. High temperature strain gages were employed to measure the strain rate of the tubes. The tube samples were secured to a test specimen, basically held in place within a furnace by two plates bolfed together, one on each end of the tube. 


\subsection{TEST DESIGN}

\subsection{PERFORMANCE TEST, BACKGROUND}

The test core used to measure the performance of the recuperator for ATS uses an air cell design designated as the High Capacity Air Cell.

The test core is shown in Figure 12. The active core lengths of the benchmark test core are 18.6" (100 air cells). The performance of the High-Capacity test core was studied for a broad range of conditions to provide a basis for the definition of the test plan. This was done using the 2D analytical method.

The data presented in this section also provided the necessary input for the design/modifications of the test rig, selection of instrumentation, and development of the test plan in such a manner so that the objectives defined below were satisfied. Unless limited by the rig setup, the conditions shown in Tables 1 and 2 were to be used for running the test. These conditions were included as part of the test plan.

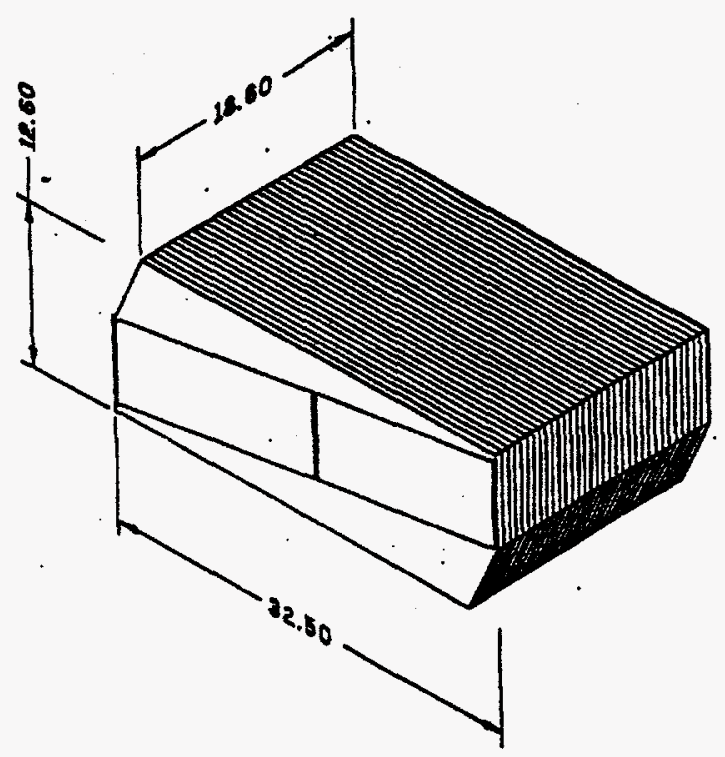

Figure 12. Test Core

Table 1. Operating Temperature and Pressures of the Benchmark Test Core

\begin{tabular}{|r|c|c|c|}
\hline \multirow{2}{*}{ Operating Condition } & \multicolumn{3}{|c|}{ Percent Engine Power Level } \\
\cline { 2 - 4 } & 100 & 70 & 30 \\
\hline Air inlet temperature, $^{\circ} \mathrm{F}$ & 489 & 400 & 280 \\
\hline Gas inlet temperature, $^{\circ} \mathrm{F}$ & 1164 & 1164 & 1164 \\
\hline Air inlet pressure, psia $^{*}$ & 91.0 & 68.0 & 44.0 \\
\hline Gas exhaust pressure, psia & 14.8 & 14.8 & 14.8 \\
\hline
\end{tabular}


Table 2. Gas and Air Flow Rate Conditions of the Benchmark Test Core

\begin{tabular}{|c|c|c|c|c|c|c|}
\hline \multirow{2}{*}{$\begin{array}{c}\text { Percent } \\
\text { Flow }\end{array}$} & \multicolumn{7}{|c|}{ Flow Rate, PPS } \\
\cline { 2 - 7 } & Gas & Air & Gas & Air & Gas & Air \\
\hline 110 & 3.83 & 3.45 & 2.88 & 2.58 & 1.79 & 1.62 \\
\hline 100 & 3.48 & 3.14 & 2.61 & 2.35 & 1.63 & 1.48 \\
\hline 90 & 3.14 & 2.82 & 2.35 & 2.12 & 1.47 & 1.33 \\
\hline 80 & 2.79 & 2.51 & 2.09 & 1.88 & 1.31 & 1.18 \\
\hline 70 & 2.44 & 2.20 & 1.83 & 1.65 & 1.14 & 1.03 \\
\hline 60 & 2.09 & 1.88 & 1.57 & 1.41 & 0.98 & 0.88 \\
\hline 50 & 1.74 & 1.57 & 1.31 & 1.18 & 0.82 & 0.74 \\
\hline
\end{tabular}

The data presented in this section were to be regarded as preliminary due to potential effects of manufacturing tolerances on the predicted performance. The results presented in this section were to be revised after the initial manufacturing development were completed and salient geometric parameters (e.g., hydraulic radius, free flow area to frontal area, core surface area density, etc.) for the core and triangular header flow passages were measured.

\subsection{TEST POINTS}

The operating conditions for testing the recuperator are defined in Tables 1 and 2. These operating conditions provide a basis for the test plan and are used for running the test. Because the part-load performance of the ATS engine was not established during the testing period, the conditions shown in Tables 1 and 2 were approximated using the 5650 engine data at $30 \%, 70 \%$, and $100 \%$ power levels. In order to predict the performance of the recuperator for a broad range of conditions, the air and gas flow rates were varied from $50 \%-110 \%$ of the full-load (100\% power) value in Table 2 .

In order to predict the performance of the recuperator for a broad range of conditions, the air and gas flow rates were varied over a wide range. The predicted performance of the full-scale core is also shown. These results are shown graphically in Figures 13-15.

\subsection{MANUFACTURING TOLERANCES}

Manufacturing toterances can affect the performance estimates provided in this section. The pretest performance predictions presented in this section are based on the geometry of the primary sheet profile as the flow passage geometry of the triangular headers on the air- and gas side of the recuperator. Due to manufacturing tolerances, these geometries will change somewhat during manufacturing

After the initial manufacturing development is completed, critical geometric parameters - such as hydraulic radius, free flow area to frontal area ratio, core surface area density, etc. - were measured for the core and triangular header flow passages. This will provide a basis for revising the data provided in this section. 


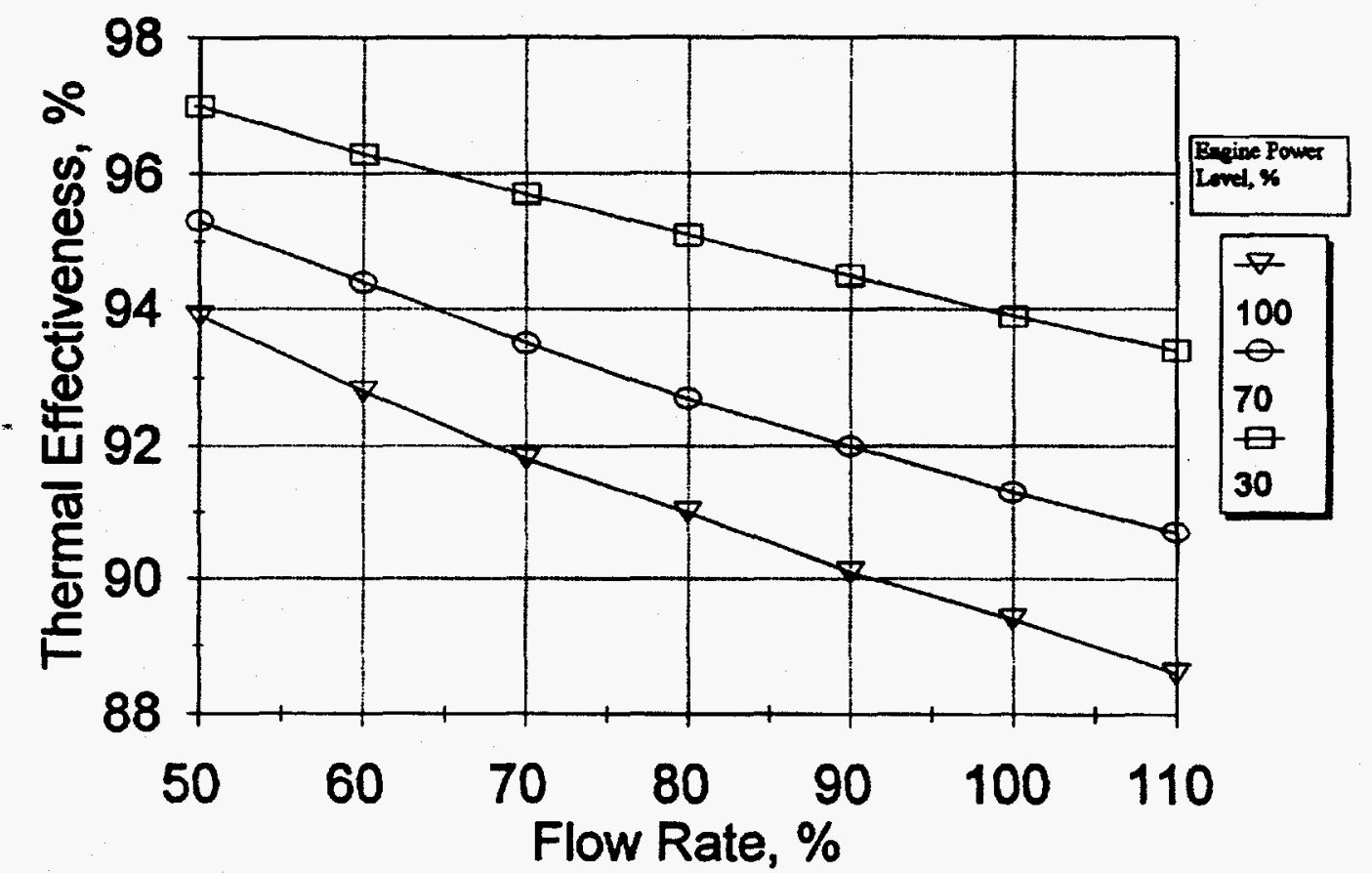

Figure 13. Effect of Flow Rate and Power Level on Thermal Effectiveness

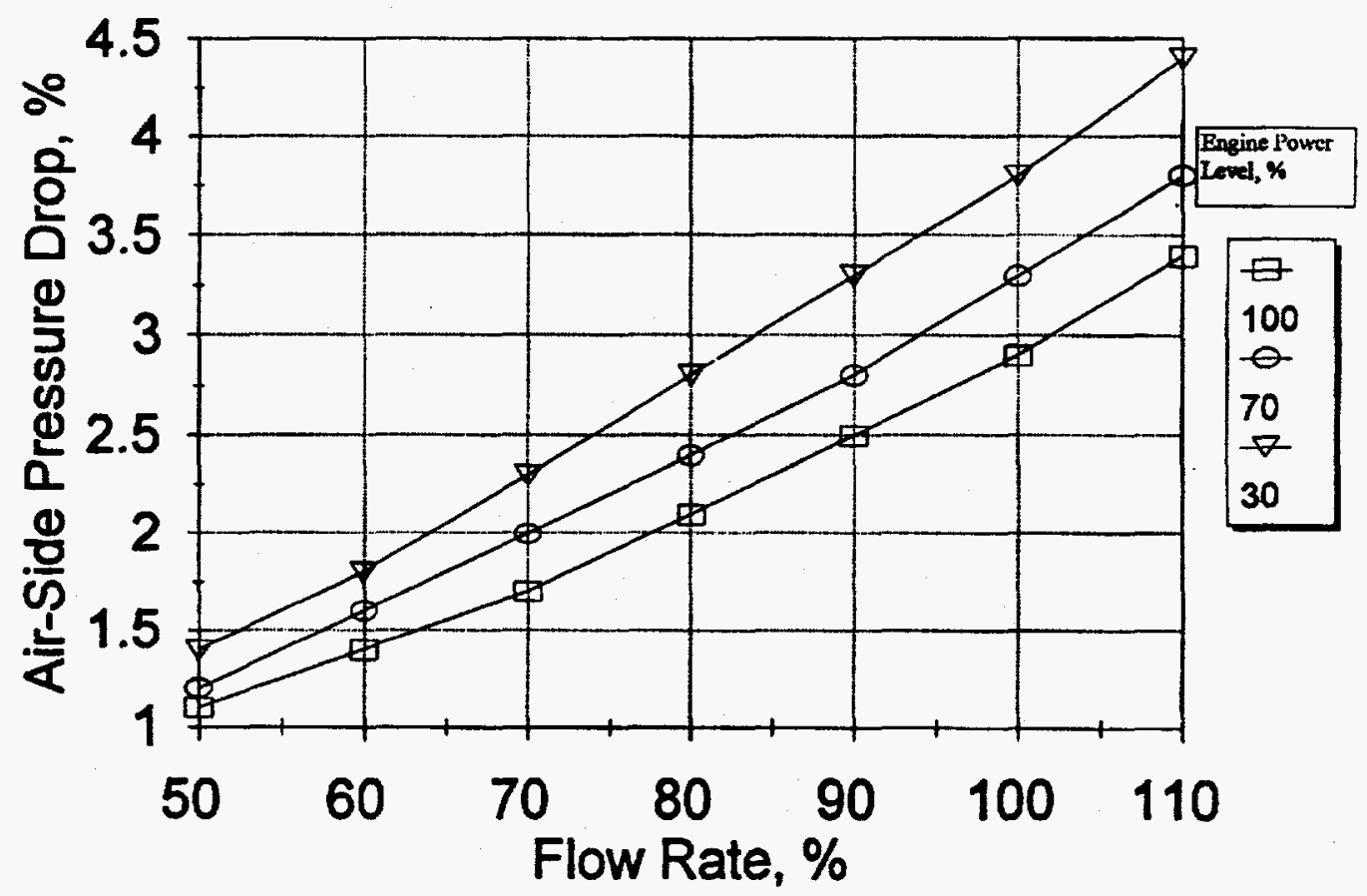

Figure 14. Effect of Flow Rate and Power Level on Air-Side Pressure Drop 


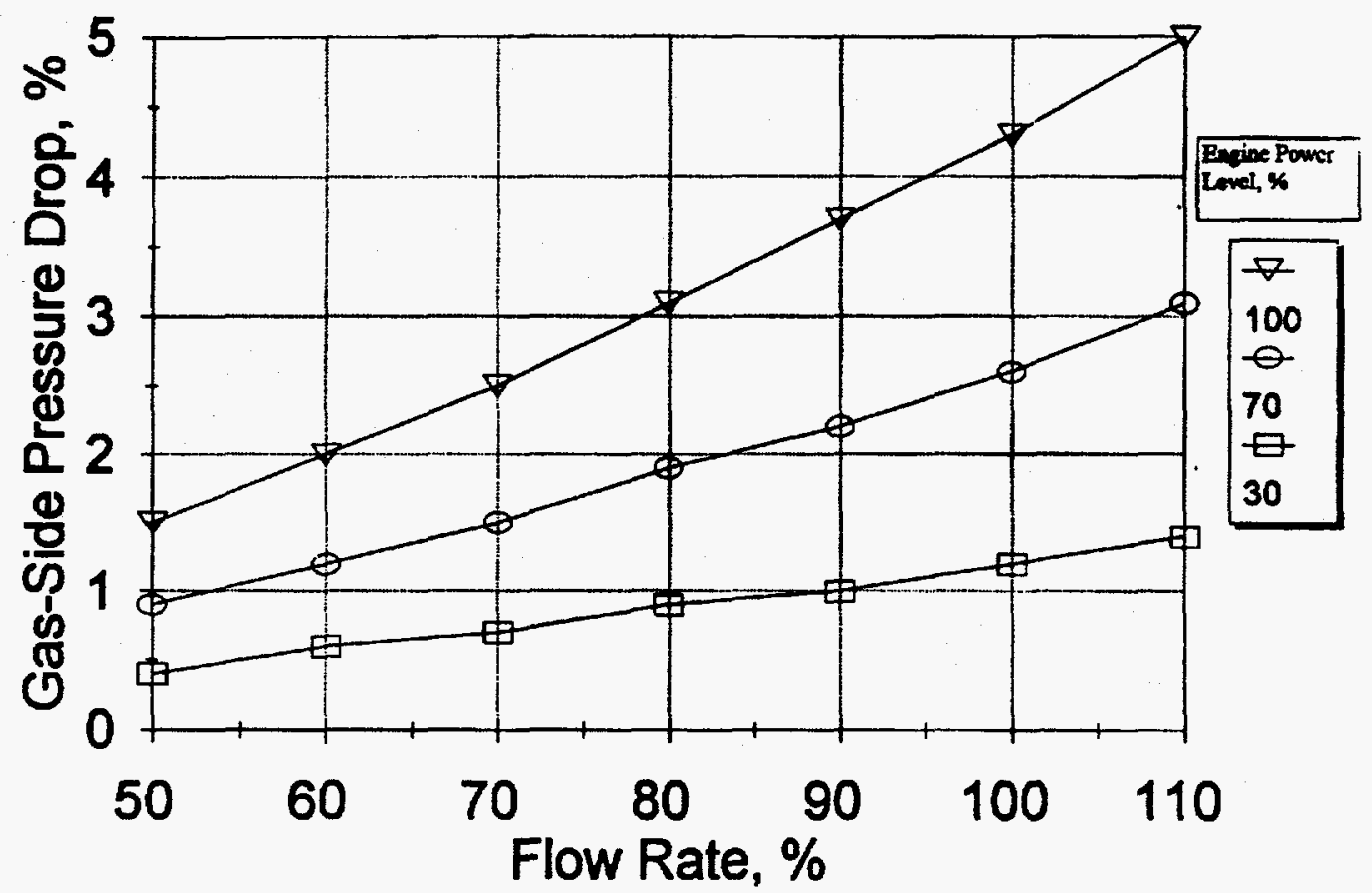

Figure 15. Effect of Flow Rate and Power Level on Gas-Side Pressure Drop 


\subsection{RESULTS AND DISCUSSION}

\subsection{TRANSIENT TEST}

The transient rig was run to obtain heat transfer surface performance data for three heat transfer surfaces. These surfaces represent the folded geometry of Solar's high capacity air cell design and are designated by number. Surface number 90 is the gas-side surface, 91 is the air-side and 92 is the combined air and gas surfaces. Surfaces 90 and 91 were manufactured using custom blades so that each side of the folded foil has the same geometry. Surface 92 was manufactured using folded foil from normal production runs.

The heat transfer and pressure drop calculations performed in the 20 analytical model rely on valid heat transfer surface performance data. These empirical data are accessed during successive iterations of the program. A combined surface, having air and gas surfaces, has been used. It is expected that separating these surfaces and getting performance data for each surface will improve the accuracy. Furthermore, heat transfer surface data on the high-capacity geometry has not been available. Past performance calculations were made using surface $\# 52$ data which is the geometrically similar 5650 surface. It is not expected that the 5650 and the high-capacity profile will differ significantly, though some differences are expected.

Surface performance data is often accepted as having an error of around 12 percent. One of the areas identified as affecting the precision of the data is small temperature gradients within room temperature air. A thermal attenuator was designed to reduce inlet air temperature fluctuations. Testing of the attenuator was done using a space heater to induce gradients in the ambient air and measuring the damping provided with the attenuator versus time. The results of these tests are summarized in Table 3. The data in graphical form is shown in Figures 16 and 17. The damping of the temperature fluctuations is visibly evident on both graphs. The unattenuated runs show significant temperature gradients whereas the damped cases are relatively flat. Due to the success from these tests, the attenuator was used for the tests of the heat transfer surfaces.

The quantification of thermal attenuation was done by calculating the standard deviation of the test data. The space heater on/off time intervals were 15 and 30 seconds. A Fourier analysis was attempted but was unsuccessful because the signal-to-noise ratio was too low in the attenuated temperature results.

An overall measurement uncertainty was estimated for the rig after implementation of the thermal attenuator and other rig modifications.

Initial testing was done on standard surfaces \#19 and \#52. Data was reproduced for each of these indicating the rig was recommissioned successfully and the integrity of the data was established. Following these runs, three high capacity surfaces were run. The results of the three surfaces are shown in Tables 4-6. Surface $\$ 90$, the gas-side only core, in shown in Table 4. The air side core, surface *91 is shown in Table 5 whereas the combined surface core (air and gas) is shown in Table 6.

As the testing was completed at the very end of this program, it was not possible to incorporate these latest results as input to the $2 \mathrm{D}$ analytical model or to determine if the goal of increased accuracy was realized. However, this will be done in the ensuing months. 
Table 3. Thermal Attenuation

\begin{tabular}{|r|l|l|l|}
\hline \multicolumn{1}{|c|}{ Condition } & \multicolumn{1}{|c|}{$\begin{array}{c}\text { Without } \\
\text { Attenuation }\end{array}$} & $\begin{array}{c}\text { With } \\
\text { Attenuation }\end{array}$ & $\begin{array}{c}\text { Ratio', } \\
(\%)\end{array}$ \\
\hline $\begin{array}{r}\text { Space Heater on/off time interval }=15 \mathrm{sec} \\
\text { (Data from 300 sec. onwards w/ attenuation) }\end{array}$ & & & \\
\hline Average Temperature, ${ }^{\circ} \mathrm{C}$ & 31.1 & 25.22 & \\
\hline Average Temperature Flucutation, ${ }^{\circ} \mathrm{C}$ & $+1-0.970$ & $+1-0.069$ & 7.11 \\
\hline $\begin{array}{l}\text { Space Heater on/off time interval }=15 \mathrm{sec} \\
\text { (Data from 180 sec. onwards w/ attenuation) }\end{array}$ & & & \\
\hline Average Temperature, ${ }^{\circ} \mathrm{C}$ & 25.38 & 29.75 & \\
\hline Average Temperature Flucutation, ${ }^{\circ} \mathrm{C}$ & $+/-1.044$ & $+1-0.146$ & 13.98 \\
\hline
\end{tabular}

${ }^{1}$ Ratio $=$ (Fluctutation $w /$ attenuation $) /($ Fluctuation $w / 0$ attenuation $)$

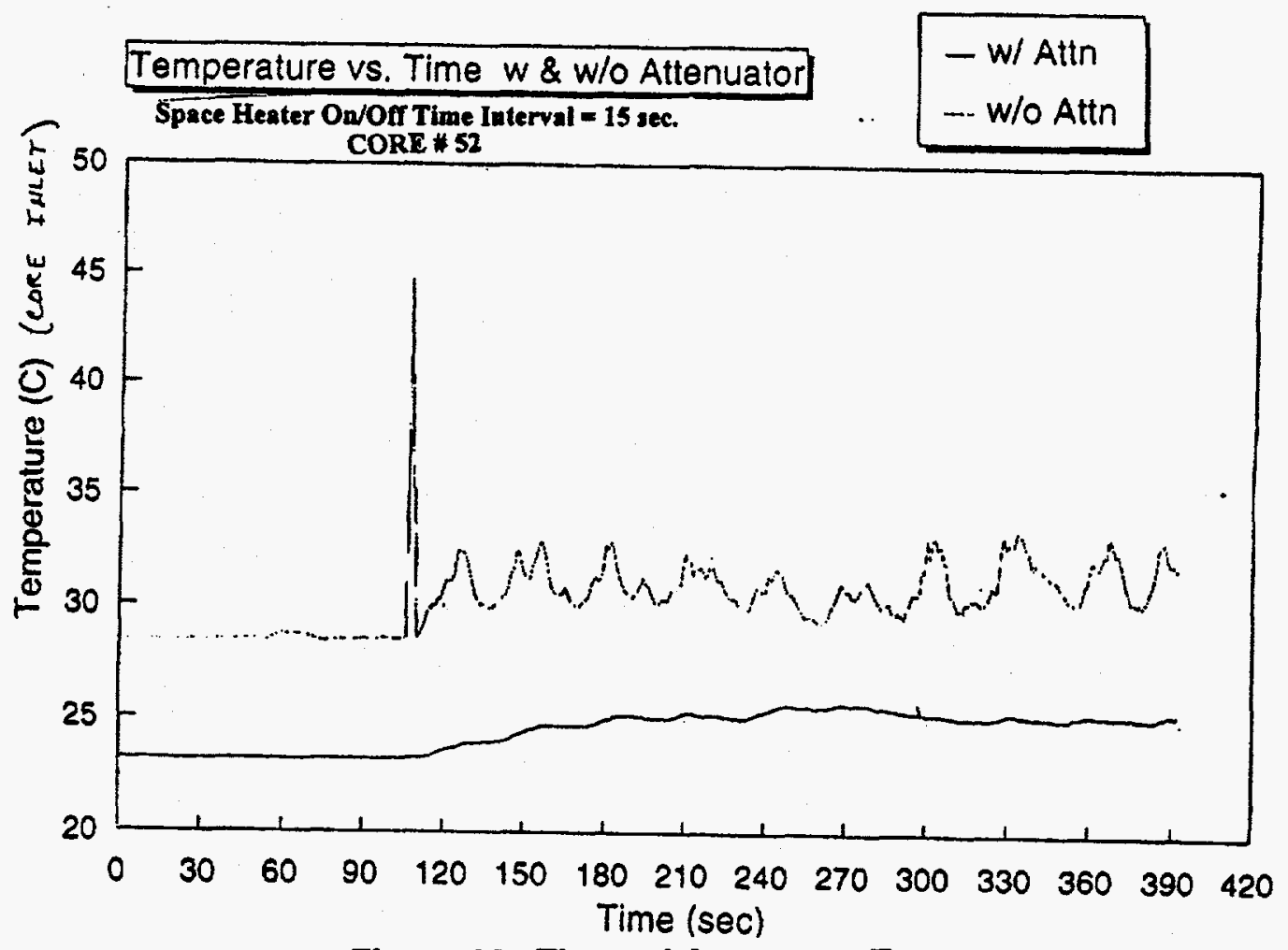

Figure 16. Thermal Attenuator Test 


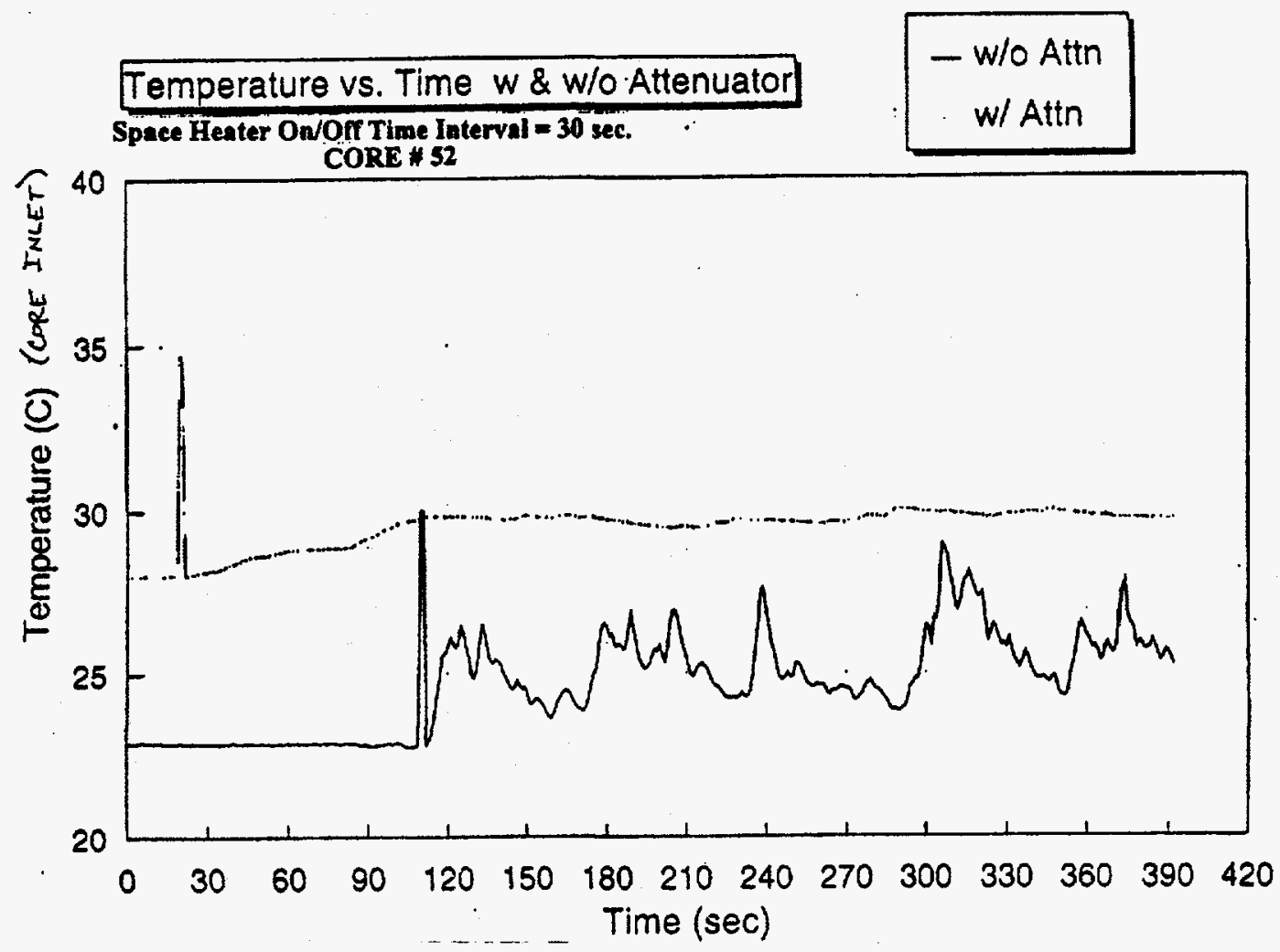

Figure 17. Thermal Attenuator Test

Table 4. Transient Performance Data for Heat Transfer Surface $\$ 90$ (gas-side)

\begin{tabular}{|c|c|c|c|c|c|c|}
\hline Quantity & Run\#1 & Run\#2 & Run*3 & Run:4 & Run\#5 & Run\#6 \\
\hline$P_{\text {barometric }}$ & 29.62 & 29.62 & 29.62 & 29.63 & 30.07 & 29.64 \\
\hline$T_{\text {embient }}$ & 72.32 & 72.32 & 72.5 & 72.32 & 72.86 & 72.68 \\
\hline$\Delta \mathrm{P}_{\text {cold orifice }}$ & 5.36 & 2.145 & 11.62 & 6.02 & 1.36 & 1.69 \\
\hline$P_{c-\text { id ontioes }}$ & 1.825 & 0.875 & 3.4 & 0.4 & 0.125 & 4.8 \\
\hline$\Delta P_{\text {costc core }}$ & 0.925 & 0.465 & 1.65 & 0.205 & 0.085 & 2.31 \\
\hline$P_{\text {cold core }}$ & 0.8 & 0.38 & 1.575 & 0.15 & 0.04 & 2.325 \\
\hline$T_{\text {cold core }}$ & 71.69 & 71.69 & 72.14 & 71.57 & 72.74 & 72.26 \\
\hline$T_{\text {cold ortheo in }}$ & 72.68 & 73.04 & 72.77 & 73.31 & 73.58 & 72.68 \\
\hline$\Delta P_{\text {ho ot oflice }}$ & 5.41 & 2.15 & 11.76 & 6 & 1.27 & 1.73 \\
\hline$P_{\text {hot ortices }}$ & 1.85 & 0.85 & 3.4 & 0.4 & 0.12 & 4.9 \\
\hline$T_{\text {hot, core, in }}$ & 92.9 & 92.72 & 92.24 & 93.86 & 94.4 & 92.18 \\
\hline$T_{\text {not, orifles, in }}$ & 87.08 & 86.72 & 88.16 & 85.64 & 83.84 & 88.16 \\
\hline $\begin{array}{l}\mathrm{T} \text {, avg time } \\
\text { lapse }\end{array}$ & 8.388 & 11.856 & 6.164 & 18.286 & 32.144 & 5.095 \\
\hline
\end{tabular}


Table 5. Transient Performance Data for Heat Transfer Surface *91 (air-side)

\begin{tabular}{|c|c|c|c|c|c|c|}
\hline Quantity & Run\#1 & Run*2 & Runk3 & Runit4 & Run*5 & Run:6 \\
\hline$P_{\text {banometric }}$ & 29.72 & 29.37 & 29.32 & 29.3 & 29.28 & 29.27 \\
\hline$T_{\text {melient }}$ & 72.86 & 71.98 & 72.32 & 72.5 & 70.34 & 70.52 \\
\hline$\Delta P_{\text {cold orthce }}$ & 3.915 & 11.672 & 5.16 & 16.67 & 3.048 & 8.075 \\
\hline$P_{\text {odid antice }}$ & 0.775 & 1.525 & 3.45 & 7.575 & 12.6 & 21.6 \\
\hline$\Delta P_{\text {colv core }}$ & 0.67 & 1.21 & 2.575 & 6.22 & 6.38 & 13.88 \\
\hline$P_{\text {cold core }}$ & 0.095 & 0.26 & 0.775 & 2.166 & 3.6 & 6.975 \\
\hline$T_{\text {colve core }}$ & 72.86 & 71.87 & 72.23 & 72.23 & 69.89 & 70.66 \\
\hline$T_{\text {cold artices in }}$ & 73.58 & 73.04 & 72.59 & 72.5 & 70.43 & 70.88 \\
\hline$\Delta P_{\text {hol arifice }}$ & 3.93 & 11.78 & 5.22 & 16.66 & 3.04 & 5.99 \\
\hline$P_{\text {hot ortilioe }}$ & 0.8 & 1.55 & 3.8 & 7.7 & 12.8 & 21.6 \\
\hline$T_{\text {hot,core, in }}$ & 91.4 & 92.84 & 92.12 & 91.76 & 91.46 & 90.27 \\
\hline$T_{\text {hod, ortilice, in }}$ & 83.84 & 84.74 & 85.82 & 87.44 & 87.08 & 88.9 \\
\hline $\begin{array}{l}T, \text { avg time } \\
\text { lapse }\end{array}$ & 28.4 & 17.4 & 11 & 7.46 & 6.78 & 4.4 \\
\hline
\end{tabular}

Table 6. Transient Performance Data for Heat Transfer Surface \#92) (Combined)

\begin{tabular}{|c|c|c|c|c|c|c|}
\hline Quantity & Run*1 & Run*2 & Run*3 & Run:44 & Run:5 & Run*6 \\
\hline$P_{\text {berometric }}$ & 29.67 & 29.67 & 29.67 & 293.66 & 29.66 & 29.65 \\
\hline$T_{\text {entient }}$ & 73.31 & 73.85 & 72.59 & 72.95 & 72.68 & 72.68 \\
\hline$\Delta P_{\text {cold artice }}$ & 3.88 & 16.795 & 5.85 & 14.625 & 2.84 & 4.45 \\
\hline$P_{\text {cold orthice }}$ & 0.37 & 1 & 2.29 & 4.61 & 8.25 & 11.775 \\
\hline$\Delta P_{\text {cold core }}$ & 0.22 & 0.59 & 1.315 & 2.5 & 4.21 & 5.83 \\
\hline$P_{\text {cold core }}$ & 0.09 & 0.32 & 0.85 & 1.9 & 3.6 & 5.35 \\
\hline$T_{\text {corte core }}$ & 73.64 & 73.79 & 72.2 & 72.32 & 72.47 & 72.32 \\
\hline$T_{\text {colv artillow in }}$ & 74.21 & 74.48 & 72.77 & 72.68 & 72.68 & 72.23 \\
\hline$\Delta P_{\text {hat oritioe }}$ & 3.696 & 16.92 & 5.894 & 14.71 & 2.86 & 4.46 \\
\hline$P_{\text {hol ortilioe }}$ & 0.35 & 1.05 & 2.3 & 4.65 & 8.3 & 11.8 \\
\hline$T_{\text {hot, core, in }}$ & 92.42 & 981.82 & 91.46 & 90.92 & 91.28 & 90.56 \\
\hline$T_{\text {not,oritioe in }}$ & 82.76 & 85.28 & 86.72 & 86.9 & 87.44 & 87.08 \\
\hline $\mathrm{T}$, avg time lapse & 29.8 & 17.5 & 11.16 & 7.73 & 58.81 & 4.88 \\
\hline
\end{tabular}




\subsection{PERFORMANCE TEST}

The performance test was run to acquire pressure drop and effectiveness data over a broad range of conditions using a core based on the high capacity air cell. This section provides a summary of the test results. The thermal effectiveness and pressure drop values on the air-and gas-sides of the recuperator are also compared against the analytical prediction of the recuperator performance as predicted by the $2 \mathrm{D}$ analytical model.

Previous rig tests of this recuperator demonstrated design point performance goals, but lower than predicted effectiveness at part load mass flow rates. The heat balance deviation also exceeded the target value of $3 \%$. It was anticipated that eliminating the leakage and mixing out the high gas-out temperature gradients would improve the energy balance deviation.

The high heat balance deviation problem encountered during previous tests was substantially reduced by eliminating the rig leaks, adding a gas-out mixer and more insulation to minimize the heat losses from the rig. The energy balance deviation was brought below the $3 \%$ limit for the majority of the test points. At the lower mass flow rates the higher heat balance deviation was attributed to an internal core leak which may explain the large-than-normal deviation between predicted and measured effectiveness values. While the leaks were reduced for the majority of the test, they did increase as testing continued. The leaks that developed with this core were the result of a duct/core interface design that is not seen in a production core.

When testing was suspended, the recuperator core was removed from the rig for inspection and leak checking after a series of test data looked suspect. At pressures of 120 psia and mass flow rates less than $3.14 \mathrm{lb} / \mathrm{s}$ the effectiveness dropped significantly, rather than remain relatively flat or increasing as seen in all other data trends from previous tests. To further investigate the problem, data was repeated at 56 psia inlet air pressure. The measured effectiveness was lower. The effectiveness diverged from the previous test results at lower mass flow rates.

A leak check confirmed a leak of about $1.8 \%$ of rated flow rate. Physical examination at the recuperator manufacturing facility showed five leaking air cells at the gas-in edges. These leaks had existed before the current test series started but had grown. The cell could be blocked but up to eight cells would have been non-functional. This was deemed too high so the testing on this core was suspended.

The performance goals were met at the rated conditions. The thermal effectiveness was measured at $90.3 \%$ and the total pressure drop was $6.8 \%$ with a energy balance deviation of $1.4 \%$. Effectiveness values were somewhat lower than predicted values under part-load conditions. This effect has been observed in previous tests and may be due to some flow maldistribution, though this is speculation only. The measured data will be used to calibrate the $2 \mathrm{D}$ analytical model using the final results from the heat transfer surface performance test.

The Test results are summarized in Tables 7-10. These tables provide a comparison between the actual test results and the analytical prediction of the recuperator performance based on the 2D model. These tables are briefly explained in the following paragraphs.

The first three lines show the test point, date, and time when the test was conducted. The flow rate, pressure, and temperature at key points are shown next. The specific heat values, capacity rates, and heat transfer rates on the air- and gas-sides of the recuperator, thermal effectiveness and pressure drop values, and the energy balance deviation are also indicated. 
Table 7. Summary of Test Results (Test Points 4-19)

\begin{tabular}{|c|c|c|c|c|c|c|c|c|c|c|}
\hline $\begin{array}{l}\text { Test Point } \\
\text { Date } \\
\text { Time }\end{array}$ & $\begin{array}{l}0004 \\
14 \text { Sep } \\
14: 15\end{array}$ & $\begin{array}{l}0005 \\
14 \text { Sep } \\
16: 10\end{array}$ & $\begin{array}{l}0006 \\
14 \text { Sep } \\
17: 41\end{array}$ & $\begin{array}{l}0007 \\
14 \text { Sep } \\
18: 50\end{array}$ & $\begin{array}{l}0008 \\
15 \text { Sep } \\
14: 03\end{array}$ & $\begin{array}{l}0009 \\
15 \text { Sep } \\
15: 10\end{array}$ & $\begin{array}{l}0010 \\
15 \text { Sep } \\
16: 45\end{array}$ & $\begin{array}{l}0012 \\
15 \text { Sep } \\
19: 39\end{array}$ & $\begin{array}{l}0013 \\
15 \text { Sep } \\
20: 23\end{array}$ & $\begin{array}{l}0019 \\
17 \text { Oct } \\
18: 30\end{array}$ \\
\hline 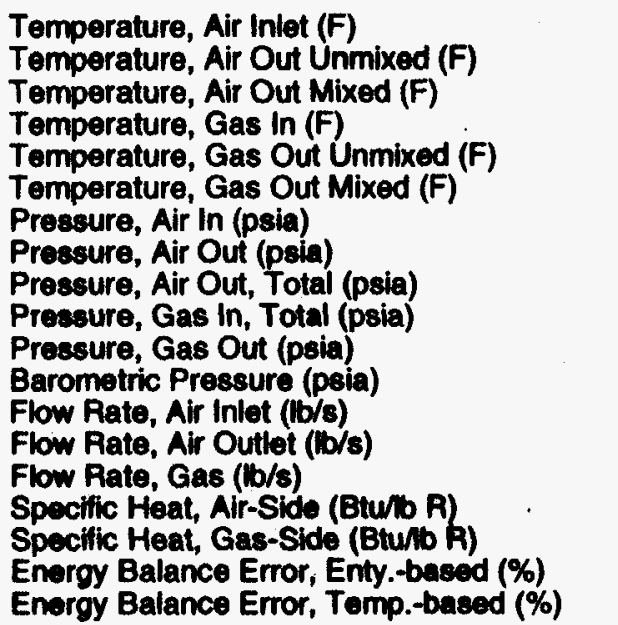 & $\begin{array}{l}517.4 \\
1118.4 \\
0 \\
1155.2 \\
604.3 \\
0 \\
56.9 \\
54.84 \\
0 \\
14.75 \\
14.47 \\
0 \\
1.932 \\
1.917 \\
2.134 \\
0.2568 \\
0.2582 \\
-1.63 \\
-1.58\end{array}$ & $\begin{array}{l}496.9 \\
1120.4 \\
0 \\
1158.7 \\
596.4 \\
0 \\
55.95 \\
52.49 \\
0 \\
14.91 \\
14.51 \\
0 \\
2.550 \\
2.521 \\
2.809 \\
0.2565 \\
0.2591 \\
-0.03 \\
0.04\end{array}$ & $\begin{array}{l}489.9 \\
1120.6 \\
0 \\
1161.9 \\
594.5 \\
0 \\
57.05 \\
52.13 \\
0 \\
15.10 \\
14.57 \\
0 \\
3.126 \\
3.118 \\
3.460 \\
0.2564 \\
0.2591 \\
-0.45 \\
-0.38\end{array}$ & $\begin{array}{l}579.3 \\
1125.7 \\
0 \\
1163.0 \\
665.8 \\
0 \\
57.34 \\
52.24 \\
0 \\
15.12 \\
14.59 \\
0 \\
3.132 \\
3.129 \\
3.462 \\
0.2578 \\
0.2602 \\
-1.23 \\
-1.19\end{array}$ & $\begin{array}{l}342.5 \\
1112.5 \\
0 \\
1161.2 \\
459.3 \\
0 \\
55.83 \\
53.89 \\
0 \\
14.68 \\
14.43 \\
0 \\
1.897 \\
1.890 \\
2.108 \\
0.2544 \\
0.2572 \\
-1.92 \\
-1.76\end{array}$ & $\begin{array}{l}340.1 \\
1111.9 \\
0 \\
1160.1 \\
469.0 \\
0 \\
56.27 \\
53.03 \\
0 \\
14.84 \\
14.47 \\
0 \\
2.545 \\
2.538 \\
2.830 \\
0.2543 \\
0.2574 \\
-0.50 \\
-0.33\end{array}$ & $\begin{array}{l}341.2 \\
1110.6 \\
0 \\
1160.3 \\
475.4 \\
0 \\
55.17 \\
50.36 \\
0 \\
15.03 \\
14.53 \\
0 \\
3.155 \\
3.139 \\
3.490 \\
0.2543 \\
0.2574 \\
0.35 \\
0.52\end{array}$ & $\begin{array}{l}575.6 \\
1122.6 \\
0 \\
1156.9 \\
652.8 \\
0 \\
56.66 \\
54.60 \\
0 \\
14.68 \\
14.41 \\
0 \\
1.883 \\
1.894 \\
2.114 \\
0.2578 \\
0.2599 \\
-3.53 \\
-3.49\end{array}$ & $\begin{array}{l}578.1 \\
1124.5 \\
0 \\
1161.5 \\
660.2 \\
0 \\
56.04 \\
52.48 \\
0 \\
14.87 \\
14.47 \\
0 \\
2.530 \\
2.539 \\
2.822 \\
0.2578 \\
0.2601 \\
-2.67 \\
-2.63\end{array}$ & $\begin{array}{l}489.9 \\
1112.5 \\
0 \\
1160.3 \\
602.7 \\
0 \\
90.56 \\
84.96 \\
0 \\
15.67 \\
14.79 \\
0 \\
4.327 \\
4.482 \\
4.984 \\
0.2563 \\
0.2592 \\
-4.47 \\
-4.40\end{array}$ \\
\hline $\begin{array}{l}\text { Effectiveness, Solar air-eide (\%) } \\
\text { Effectiveness, CAT air-side }(\%) \\
\text { Effectiveness, Solar gas-8ide }(\%) \\
\text { Effectiveness, Solar's } 20 \text { prediction (\%) }\end{array}$ & $\begin{array}{l}91.4 \\
91.4 \\
92.9 \\
92.5\end{array}$ & $\begin{array}{l}91.2 \\
91.2 \\
91.2 \\
90.6\end{array}$ & $\begin{array}{l}90.7 \\
90.7 \\
91.1 \\
89.2\end{array}$ & $\begin{array}{l}90.6 \\
90.5 \\
91.7 \\
89.3\end{array}$ & $\begin{array}{l}91.0 \\
91.1 \\
92.8 \\
92.6\end{array}$ & $\begin{array}{l}90.8 \\
91.0 \\
91.3 \\
90.9\end{array}$ & $\begin{array}{l}90.4 \\
90.6 \\
90.1 \\
89.2\end{array}$ & $\begin{array}{l}91.3 \\
91.3 \\
94.7 \\
93.1\end{array}$ & $\begin{array}{l}90.8 \\
90.8 \\
93.3 \\
91.0\end{array}$ & $\begin{array}{l}89.3 \\
89.3 \\
93.5 \\
87.9\end{array}$ \\
\hline $\begin{array}{l}\text { Air-Side Pressure Drop, Solar }(\%) \\
\text { Air-Side Pressure Drop, CAT HILO }(\%) \\
\text { Air-Side Pressure Drop, CAT DELP }(\%) \\
\text { Air-Side Pressure Drop, 2D prediction }(\%)\end{array}$ & $\begin{array}{l}3.61 \\
3.61 \\
3.58 \\
3.80\end{array}$ & $\begin{array}{l}6.19 \\
6.19 \\
6.07 \\
5.90\end{array}$ & $\begin{array}{l}8.62 \\
8.62 \\
8.50 \\
7.70\end{array}$ & $\begin{array}{l}8.89 \\
8.89 \\
8.76 \\
8.00\end{array}$ & $\begin{array}{l}3.46 \\
3.46 \\
3.41 \\
3.50\end{array}$ & $\begin{array}{l}5.76 \\
5.76 \\
5.68 \\
5.30\end{array}$ & $\begin{array}{l}8.71 \\
8.71 \\
8.70 \\
7.60\end{array}$ & $\begin{array}{l}3.63 \\
3.63 \\
3.56 \\
3.80\end{array}$ & $\begin{array}{l}6.35 \\
6.35 \\
6.25 \\
6.10\end{array}$ & $\begin{array}{l}6.18 \\
6.18 \\
6.09 \\
4.90\end{array}$ \\
\hline $\begin{array}{l}\text { Gas-Side Pressure Drop, Solar (\%) } \\
\text { Ga-Side Pressure Drop, CAT HLO (\%) } \\
\text { Gas-Side Pressure Drop, CAT DELP (\%) } \\
\text { Gas-Side Pressure Drop, 2D prediction (\%) }\end{array}$ & $\begin{array}{l}1.84 \\
1.84 \\
1.85 \\
2.10\end{array}$ & $\begin{array}{l}2.64 \\
2.64 \\
2.65 \\
3.20\end{array}$ & $\begin{array}{l}3.47 \\
3.47 \\
3.48 \\
4.40\end{array}$ & $\begin{array}{l}3.55 \\
3.55 \\
3.56 \\
4.60\end{array}$ & $\begin{array}{l}1.73 \\
1.73 \\
1.74 \\
1.90\end{array}$ & $\begin{array}{l}2.54 \\
2.54 \\
2.56 \\
3.00\end{array}$ & $\begin{array}{l}3.37 \\
3.37 \\
3.39 \\
4.20\end{array}$ & $\begin{array}{l}1.84 \\
1.84 \\
1.85 \\
2.20\end{array}$ & $\begin{array}{l}2.69 \\
2.69 \\
2.70 \\
3.40\end{array}$ & $\begin{array}{l}5.64 \\
5.64 \\
5.63 \\
7.60\end{array}$ \\
\hline
\end{tabular}


Table 8. Summary of Test Results (Test Points 21-35)

\begin{tabular}{|c|c|c|c|c|c|c|c|c|c|c|}
\hline $\begin{array}{l}\text { Test Point } \\
\text { Date } \\
\text { Time }\end{array}$ & $\begin{array}{l}0021 \\
17 \text { Oct } \\
19: 52\end{array}$ & $\begin{array}{l}0022 \\
17 \mathrm{Oct} \\
21: 02\end{array}$ & $\begin{array}{l}0023 \\
17 \text { Oct } \\
22: 19\end{array}$ & $\begin{array}{l}0024 \\
17 \text { Oct } \\
23: 34\end{array}$ & $\begin{array}{l}0025 \\
18 \text { Oct } \\
01: 26\end{array}$ & $\begin{array}{l}0026 \\
18 \text { Oct } \\
02: 19\end{array}$ & $\begin{array}{l}0032 \\
25 \text { Oct } \\
22: 43\end{array}$ & $\begin{array}{l}0033 \\
26 \mathrm{Oct} \\
00: 08\end{array}$ & $\begin{array}{l}0034 \\
26 \text { Oct } \\
01: 33\end{array}$ & $\begin{array}{l}0035 \\
26 \text { Oct } \\
19: 09\end{array}$ \\
\hline $\begin{array}{l}\text { Temperature, Air Inlet (F) } \\
\text { Temperature, Air Out Unmixed (F) } \\
\text { Temperature, Air Out Mixed (F) } \\
\text { Temperature, Gas In (F) } \\
\text { Temperature, Gas Out Unmixed (F) } \\
\text { Temperature, Gas Out Mixed (F) } \\
\text { Pressure, Air In (psia) } \\
\text { Pressure, Air Out (psia) } \\
\text { Pressure, Air Out, Total (psia) } \\
\text { Pressure, Gas In, Total (psia) } \\
\text { Pressure, Gas Out (psia) } \\
\text { Barometric Pressure (psia) } \\
\text { Flow Rate, Air Inlet (b/s) } \\
\text { Flow Rate, Air Outlet (1b/s) } \\
\text { Flow Rate, Gas ((b/s) } \\
\text { Specific Heat, Air-Side (Btu/no P) } \\
\text { Specific Heat, Gas-Side (Btuhb R) } \\
\text { Energy Balance Error, Enty.-baced (\%) } \\
\text { Energy Balance Error, Temp.-based (\%) }\end{array}$ & $\begin{array}{l}489.5 \\
1114.2 \\
0 \\
1159.0 \\
599.5 \\
0 \\
91.65 \\
87.54 \\
0 \\
15.38 \\
14.67 \\
0 \\
3.661 \\
3.810 \\
4.237 \\
0.2563 \\
0.2592 \\
4.87 \\
4.80\end{array}$ & $\begin{array}{l}490.4 \\
1118.4 \\
0 \\
1159.5 \\
598.5 \\
0 \\
91.02 \\
88.09 \\
0 \\
15.13 \\
14.59 \\
0 \\
3.019 \\
3.163 \\
3.532 \\
0.2564 \\
0.2592 \\
-5.55 \\
-5.48\end{array}$ & $\begin{array}{l}489.5 \\
1118.0 \\
0 \\
1160.8 \\
592.5 \\
0 \\
90.82 \\
88.80 \\
0 \\
14.92 \\
14.51 \\
0 \\
2.440 \\
2.567 \\
2.854 \\
0.2563 \\
0.2591 \\
-6.72 \\
-6.65\end{array}$ & $\begin{array}{l}490.3 \\
1112.5 \\
0 \\
1157.1 \\
586.5 \\
0 \\
92.72 \\
91.58 \\
0 \\
14.72 \\
14.45 \\
0 \\
1.745 \\
1.891 \\
2.114 \\
0.2563 \\
0.2590 \\
-10.19 \\
-10.12\end{array}$ & $\begin{array}{l}580.1 \\
1121.2 \\
0 \\
1162.4 \\
675.7 \\
0 \\
90.87 \\
85.09 \\
0 \\
15.69 \\
14.78 \\
0 \\
4.339 \\
4.473 \\
4.971 \\
0.2577 \\
0.2604 \\
4.20 \\
-4.16\end{array}$ & $\begin{array}{l}580.6 \\
1121.9 \\
0 \\
1160.1 \\
672.4 \\
0 \\
90.80 \\
86.45 \\
0 \\
15.40 \\
14.67 \\
0 \\
3.702 \\
3.842 \\
4.266 \\
0.2578 \\
0.2603 \\
-4.99 \\
-4.95\end{array}$ & $\begin{array}{l}579.8 \\
1119.7 \\
0 \\
1159.5 \\
669.8 \\
0 \\
91.71 \\
88.75 \\
0 \\
15.28 \\
14.72 \\
0 \\
2.947 \\
3.156 \\
3.518 \\
0.2577 \\
0.2602 \\
-8.47 \\
-8.43\end{array}$ & $\begin{array}{l}579.7 \\
1119.8 \\
0 \\
1158.9 \\
664.9 \\
0 \\
91.35 \\
89.34 \\
0 \\
15.06 \\
14.65 \\
0 \\
2.352 \\
2.535 \\
2.826 \\
0.2577 \\
0.2602 \\
-9.65 \\
-9.61\end{array}$ & $\begin{array}{l}579.2 \\
1115.7 \\
0 \\
1158.3 \\
659.0 \\
0 \\
90.76 \\
89.57 \\
0 \\
14.87 \\
14.59 \\
0 \\
1.710 \\
1.902 \\
2.122 \\
0.2577 \\
0.2601 \\
-13.26 \\
-13.23\end{array}$ & $\begin{array}{l}489.3 \\
1106.0 \\
0 \\
1159.7 \\
606.6 \\
0 \\
120.83 \\
116.88 \\
0 \\
15.80 \\
14.91 \\
0 \\
4.171 \\
4.466 \\
4.992 \\
0.2562 \\
0.2593 \\
-7.80 \\
-7.72\end{array}$ \\
\hline $\begin{array}{l}\text { Effectiveness, Solar air-side (\%) } \\
\text { Effectiveness, CAT air-side (\%) } \\
\text { Effectiveness, Solar ges-aide (\%) } \\
\text { Effectiveness, Solar's } 20 \text { prediction }(\%)\end{array}$ & $\begin{array}{l}89.8 \\
89.8 \\
94.4 \\
89.4\end{array}$ & $\begin{array}{l}90.3 \\
90.3 \\
95.6 \\
91.1\end{array}$ & $\begin{array}{l}90.1 \\
90.1 \\
96.6 \\
92.6\end{array}$ & $\begin{array}{l}90.2 \\
90.2 \\
100.4 \\
95.3\end{array}$ & $\begin{array}{l}89.5 \\
89.5 \\
93.5 \\
87.7\end{array}$ & $\begin{array}{l}89.9 \\
89.9 \\
94.6 \\
89.3\end{array}$ & $\begin{array}{l}89.8 \\
89.8 \\
98.1 \\
91.9\end{array}$ & $\begin{array}{l}89.8 \\
89.8 \\
99.4 \\
93.6\end{array}$ & $\begin{array}{l}89.6 \\
89.5 \\
103.2 \\
86.0\end{array}$ & $\begin{array}{l}88.8 \\
88.8 \\
96.3 \\
89.3\end{array}$ \\
\hline $\begin{array}{l}\text { Air-Side Prescure Drop, Soler (\%) } \\
\text { Air-Side Pressure Drop, CAT HILO (\%) } \\
\text { Air-Side Pressure Drop, CAT DELP (\%) } \\
\text { Air-Side Pressure Drop, } 20 \text { prediction }(\%)\end{array}$ & $\begin{array}{l}4.47 \\
4.47 \\
4.43 \\
3.70\end{array}$ & $\begin{array}{l}3.23 \\
3.23 \\
3.21 \\
2.80\end{array}$ & $\begin{array}{l}2.22 \\
2.22 \\
2.22 \\
2.10\end{array}$ & $\begin{array}{l}1.23 \\
1.23 \\
1.23 \\
1.20\end{array}$ & $\begin{array}{l}6.36 \\
6.36 \\
6.07 \\
5.20\end{array}$ & $\begin{array}{l}4.80 \\
4.80 \\
4.77 \\
4.00\end{array}$ & $\begin{array}{l}3.23 \\
3.23 \\
3.22 \\
2.80\end{array}$ & $\begin{array}{l}2.20 \\
2.20 \\
2.20 \\
2.00\end{array}$ & $\begin{array}{l}1.32 \\
1.32 \\
1.31 \\
1.30\end{array}$ & $\begin{array}{l}3.27 \\
3.27 \\
3.26 \\
2.60\end{array}$ \\
\hline $\begin{array}{l}\text { Gas-Side Pressure Drop, Solar (\%) } \\
\text { Gas-Side Pressure Drop, CAT HILO }(\%) \\
\text { Gas-Side Pressure Drop, CAT DELP }(\%) \\
\text { Gas-Side Pressure Drop, 2D prediction (\%) }\end{array}$ & $\begin{array}{l}4.58 \\
4.58 \\
4.57 \\
6.00\end{array}$ & $\begin{array}{l}3.60 \\
3.60 \\
3.60 \\
4.60\end{array}$ & $\begin{array}{l}2.72 \\
2.72 \\
2.72 \\
3.30\end{array}$ & $\begin{array}{l}1.85 \\
1.85 \\
1.86 \\
2.10\end{array}$ & $\begin{array}{l}5.75 \\
5.75 \\
5.75 \\
7.80\end{array}$ & $\begin{array}{l}4.73 \\
4.73 \\
4.73 \\
6.30\end{array}$ & $\begin{array}{l}3.61 \\
3.61 \\
3.59 \\
4.70\end{array}$ & $\begin{array}{l}2.72 \\
2.72 \\
2.69 \\
3.40\end{array}$ & $\begin{array}{l}1.88 \\
1.80 \\
1.87 \\
2.20\end{array}$ & $\begin{array}{l}5.63 \\
5.63 \\
5.61 \\
7.50\end{array}$ \\
\hline
\end{tabular}


Table 9. Summary of Test Results (Test Points 36-45)

\begin{tabular}{|c|c|c|c|c|c|c|c|c|c|c|}
\hline $\begin{array}{l}\text { Test Point } \\
\text { Date } \\
\text { Time }\end{array}$ & $\begin{array}{l}0036 \\
26 \text { Oct } \\
20: 39\end{array}$ & $\begin{array}{l}0037 \\
26 \text { Oct } \\
22: 24\end{array}$ & $\begin{array}{l}0038 \\
27 \text { Oct } \\
00: 32\end{array}$ & $\begin{array}{l}0039 \\
27 \text { Oct } \\
01: 58\end{array}$ & $\begin{array}{l}0040 \\
28 \text { Oct } \\
18: 48\end{array}$ & $\begin{array}{l}0041 \\
28 \text { Oct } \\
00: 04\end{array}$ & $\begin{array}{l}0042 \\
28 \text { Oct } \\
01: 30\end{array}$ & $\begin{array}{l}0043 \\
28 \text { Oct } \\
02: 56\end{array}$ & $\begin{array}{l}0044 \\
28 \text { Oct } \\
04: 24\end{array}$ & $\begin{array}{l}0045 \\
30 \text { Oct } \\
13: 52\end{array}$ \\
\hline $\begin{array}{l}\text { Temperature, Air Inlet (F) } \\
\text { Temperature, Air Out Unmixed (F) } \\
\text { Temperature, Air Out Mixed (F) } \\
\text { Temperature, Gas In (F) } \\
\text { Temperature, Gas Out Unmixed (F) } \\
\text { Temperature, Gas Out Mixed (F) } \\
\text { Presesure, Air In (psia) } \\
\text { Pressure, Air Out (psia) } \\
\text { Pressure, Air Out, Total (psia) } \\
\text { Preseure, Gas In, Total (psia) } \\
\text { Pressure, Gas Out (psia) } \\
\text { Barometric Pressure (psia) } \\
\text { Flow Rate, Air Inlet (b/s) } \\
\text { Flow Rate, Air Outtot (b/s) } \\
\text { Flow Rate, Gas (b/s) } \\
\text { Specific Heat, Air-Side (Btu/b R) } \\
\text { Specilic Heat, Gas-Side (Btu/hb R) } \\
\text { Energy Balance Error, Enty.-based (\%) } \\
\text { Energy Balance Error, Temp.-based (\%) }\end{array}$ & $\begin{array}{l}488.7 \\
1106.4 \\
0.0 \\
1160.3 \\
600.8 \\
0.0 \\
120.31 \\
117.35 \\
0.0 \\
15.50 \\
14.80 \\
0 \\
3.542 \\
3.828 \\
4.246 \\
0.2562 \\
0.2592 \\
-8.79 \\
-8.72\end{array}$ & $\begin{array}{l}489.0 \\
1105.6 \\
0.0 \\
1158.7 \\
598.2 \\
0.0 \\
119.87 \\
117.75 \\
0.0 \\
15.27 \\
14.72 \\
0 \\
2.892 \\
3.173 \\
3.537 \\
0.2562 \\
0.2592 \\
-10.39 \\
-10.32\end{array}$ & $\begin{array}{l}489.0 \\
1104.3 \\
0.0 \\
1159.1 \\
592.3 \\
0.0 \\
119.71 \\
118.25 \\
0.0 \\
15.06 \\
14.65 \\
0 \\
2.351 \\
2.607 \\
2.891 \\
0.2562 \\
0.2591 \\
-11.97 \\
-11.90\end{array}$ & $\begin{array}{l}489.1 \\
1098.6 \\
0.0 \\
1159.6 \\
590.1 \\
0.0 \\
119.49 \\
118.67 \\
0.0 \\
14.86 \\
14.58 \\
0 \\
1.620 \\
1.919 \\
2.137 \\
0.2561 \\
0.2592 \\
-18.60 \\
-18.54\end{array}$ & $\begin{array}{l}579.8 \\
1112.8 \\
0.0 \\
1159.5 \\
678.5 \\
0.0 \\
119.89 \\
115.65 \\
0.0 \\
15.78 \\
14.86 \\
0 \\
4.212 \\
4.523 \\
5.037 \\
0.2576 \\
0.2604 \\
-8.33 \\
-8.29\end{array}$ & $\begin{array}{l}579.8 \\
1113.1 \\
0.0 \\
1159.5 \\
674.6 \\
0.0 \\
120.81 \\
117.79 \\
0.0 \\
15.45 \\
14.72 \\
0 \\
3.492 \\
3.801 \\
4.226 \\
0.2576 \\
0.2603 \\
-9.84 \\
-9.80\end{array}$ & $\begin{array}{l}579.9 \\
1114.4 \\
0.0 \\
1159.7 \\
671.1 \\
0.0 \\
120.56 \\
118.43 \\
0.0 \\
15.18 \\
14.63 \\
0 \\
2.832 \\
3.139 \\
3.496 \\
0.2577 \\
0.2603 \\
-11.80 \\
-11.77\end{array}$ & $\begin{array}{l}579.6 \\
1112.5 \\
0.0 \\
1159.8 \\
666.5 \\
0.0 \\
119.79 \\
118.36 \\
0.0 \\
14.96 \\
14.55 \\
0 \\
2.257 \\
2.503 \\
2.790 \\
0.2576 \\
0.2603 \\
-12.80 \\
-12.76\end{array}$ & $\begin{array}{l}580.1 \\
1102.3 \\
0.0 \\
1159.2 \\
664.2 \\
0.0 \\
120.95 \\
120.16 \\
0.0 \\
14.75 \\
14.48 \\
0 \\
1.575 \\
1.859 \\
2.080 \\
0.2575 \\
0.2603 \\
-19.44 \\
-19.40\end{array}$ & $\begin{array}{l}580.5 \\
1111.1 \\
0.0 \\
1159.3 \\
670.4 \\
0.0 \\
56.51 \\
46.37 \\
0.0 \\
15.72 \\
14.85 \\
0 \\
4.414 \\
4.493 \\
4.865 \\
0.2576 \\
0.2602 \\
-3.22 \\
-3.17\end{array}$ \\
\hline $\begin{array}{l}\text { Effectivenees, Solar alr-side }(\%) \\
\text { Effectiveness, CAT air-side }(\%) \\
\text { Effectiveness, Solar gas-side }(\%) \\
\text { Effectiveness, Solar's } 20 \text { prediction }(\%)\end{array}$ & $\begin{array}{l}88.8 \\
88.8 \\
97.3 \\
90.7\end{array}$ & $\begin{array}{l}89.0 \\
89.0 \\
99.3 \\
92.6\end{array}$ & $\begin{array}{l}88.6 \\
88.6 \\
100.6 \\
94.0\end{array}$ & $\begin{array}{l}87.6 \\
87.7 \\
107.6 \\
97.2\end{array}$ & $\begin{array}{l}88.8 \\
88.8 \\
96.8 \\
89.2\end{array}$ & $\begin{array}{l}88.8 \\
88.8 \\
98.5 \\
91.0\end{array}$ & $\begin{array}{l}88.8 \\
88.8 \\
100.7 \\
93.0\end{array}$ & $\begin{array}{l}88.4 \\
88.4 \\
101.4 \\
94.4\end{array}$ & $\begin{array}{l}87.2 \\
87.2 \\
108.3 \\
97.3\end{array}$ & $\begin{array}{l}88.3 \\
88.3 \\
91.3 \\
86.4\end{array}$ \\
\hline $\begin{array}{l}\text { Air-Side Pressure Drop, Solar }(\%) \\
\text { Air-Side Pressure Drop, CAT HIL (\%) } \\
\text { Air-Side Pressure Drop, CAT DELP }(\%) \\
\text { Air-Side Pressure Drop, } 20 \text { prediction }(\%)\end{array}$ & $\begin{array}{l}2.46 \\
2.46 \\
2.45 \\
2.00\end{array}$ & $\begin{array}{l}1.77 \\
1.77 \\
1.77 \\
1.50\end{array}$ & $\begin{array}{l}1.23 \\
1.23 \\
1.24 \\
1.10\end{array}$ & $\begin{array}{l}0.69 \\
0.69 \\
0.70 \\
0.70\end{array}$ & $\begin{array}{l}3.53 \\
3.53 \\
3.51 \\
2.80\end{array}$ & $\begin{array}{l}2.50 \\
2.50 \\
2.50 \\
2.10\end{array}$ & $\begin{array}{l}1.76 \\
1.76 \\
1.76 \\
1.50\end{array}$ & $\begin{array}{l}1.20 \\
1.20 \\
1.20 \\
1.10\end{array}$ & $\begin{array}{l}0.65 \\
0.65 \\
0.66 \\
0.70\end{array}$ & $\begin{array}{l}17.94 \\
17.94 \\
0.14 \\
14.30\end{array}$ \\
\hline $\begin{array}{l}\text { Gas-Side Pressure Drop, Solar }(\%) \\
\text { Gas-Side Pressure Drop, CAT HILO (\%) } \\
\text { Gas-Side Pressure Drop, CAT DELP }(\%) \\
\text { Gas-Side Pressure Drop, 2D prediction (\%) }\end{array}$ & $\begin{array}{l}4.52 \\
4.52 \\
4.52 \\
6.00\end{array}$ & $\begin{array}{l}3.59 \\
3.59 \\
3.59 \\
4.60\end{array}$ & $\begin{array}{l}2.75 \\
2.75 \\
2.74 \\
3.40\end{array}$ & $\begin{array}{l}1.86 \\
1.86 \\
1.85 \\
2.20\end{array}$ & $\begin{array}{l}5.86 \\
5.86 \\
\mathbf{5 . 8 6} \\
\mathbf{8 . 0 0}\end{array}$ & $\begin{array}{l}4.68 \\
4.68 \\
4.66 \\
6.20\end{array}$ & $\begin{array}{l}3.64 \\
3.64 \\
3.60 \\
4.70\end{array}$ & $\begin{array}{l}2.75 \\
2.75 \\
2.74 \\
3.40\end{array}$ & $\begin{array}{l}1.85 \\
1.85 \\
1.84 \\
2.20\end{array}$ & $\begin{array}{l}\mathbf{5 . 5 0} \\
\mathbf{5 . 5 0} \\
\mathbf{5 . 4 9} \\
\mathbf{7 . 4 0}\end{array}$ \\
\hline
\end{tabular}




\section{Table 10. Summary of Test Results (Test Points 47-50)}

\begin{tabular}{|c|c|c|c|c|}
\hline $\begin{array}{l}\text { Test Point } \\
\text { Date } \\
\text { Time }\end{array}$ & $\begin{array}{l}0047 \\
30 \text { Oct } \\
15: 15\end{array}$ & $\begin{array}{l}0048 \\
30 \text { Oct } \\
16: 26\end{array}$ & $\begin{array}{l}0049 \\
30 \text { Oct } \\
17: 43\end{array}$ & $\begin{array}{l}0050 \\
30 \text { Oct } \\
19: 09\end{array}$ \\
\hline $\begin{array}{l}\text { Temperature, Air Inlet (F) } \\
\text { Temperature, Air Out Unmixed (F) } \\
\text { Temperature, Air Out Mixed (F) } \\
\text { Temperature, Gas In (F) } \\
\text { Temperature, Gas Out Unmixed (F) } \\
\text { Temperature, Gas Out Mixed (F) } \\
\text { Pressure, Air In (psia) } \\
\text { Pressure, Air Out (psia) } \\
\text { Pressure, Air Out, Total (psia) } \\
\text { Pressure, Gas In, Total (psia) } \\
\text { Pressure, Gas Out (psia) } \\
\text { Barometric Pressure (psia) } \\
\text { Flow Rate, Air Inlet (lb/s) } \\
\text { Flow Rate, Air Outlet (lb/s) } \\
\text { Flow Rate, Gas (lb/s) } \\
\text { Specific Heat, Air-Side (Btu/hb R) } \\
\text { Specific Heat, Gas-Side (Btu/b R) } \\
\text { Energy Balance Error, Enty.-based (\%) } \\
\text { Energy Balance Error, Temp.-based (\%) }\end{array}$ & $\begin{array}{l}580.5 \\
1115.4 \\
0 \\
1160.0 \\
670.4 \\
0 \\
56.19 \\
48.72 \\
0 \\
15.44 \\
14.74 \\
0 \\
3.751 \\
3.834 \\
4.199 \\
0.2577 \\
0.2602 \\
-3.58 \\
-3.54\end{array}$ & $\begin{array}{l}579.9 \\
1119.1 \\
0 \\
1159.6 \\
670.5 \\
0 \\
55.86 \\
50.65 \\
0 \\
15.19 \\
14.64 \\
0 \\
3.066 \\
3.158 \\
3.517 \\
0.2578 \\
0.2602 \\
-4.61 \\
-4.57\end{array}$ & $\begin{array}{l}579.8 \\
1120.3 \\
0 \\
1159.4 \\
666.8 \\
0 \\
56.66 \\
53.33 \\
0 \\
14.96 \\
14.56 \\
0 \\
2.391 \\
2.514 \\
2.803 \\
0.2578 \\
0.2602 \\
-7.11 \\
-7.08\end{array}$ & $\begin{array}{l}579.7 \\
1116.2 \\
0 \\
1158.5 \\
660.5 \\
0 \\
55.97 \\
53.98 \\
0 \\
14.77 \\
14.50 \\
0 \\
1.775 \\
1.898 \\
2.107 \\
0.2577 \\
0.2601 \\
-9.67 \\
-9.63\end{array}$ \\
\hline $\begin{array}{l}\text { Effectiveness, Solar air-side (\%) } \\
\text { Effectiveness, CAT air-side (\%) } \\
\text { Effectiveness, Solar gas-side (\%) } \\
\text { Effectiveness, Solar's 2D prediction (\%) }\end{array}$ & $\begin{array}{l}89.2 \\
89.2 \\
92.5 \\
88.3\end{array}$ & $\begin{array}{l}90.0 \\
90.0 \\
94.4 \\
90.5\end{array}$ & $\begin{array}{l}90.3 \\
90.3 \\
97.2 \\
92.8\end{array}$ & $\begin{array}{l}90.1 \\
90.0 \\
99.7 \\
94.9\end{array}$ \\
\hline $\begin{array}{l}\text { Air-Side Pressure Drop, Solar (\%) } \\
\text { Air-Side Pressure Drop, CAT HILO (\%) } \\
\text { Air-Side Pressure Drop, CAT DELP (\%) } \\
\text { Air-Side Pressure Drop, 2D prediction (\%) }\end{array}$ & $\begin{array}{l}13.29 \\
13.29 \\
0.14 \\
11.10\end{array}$ & $\begin{array}{l}9.32 \\
9.32 \\
9.26 \\
8.20\end{array}$ & $\begin{array}{l}5.88 \\
5.88 \\
5.83 \\
5.50\end{array}$ & $\begin{array}{l}3.56 \\
3.56 \\
3.52 \\
3.70\end{array}$ \\
\hline $\begin{array}{l}\text { Gas-Side Pressure Drop, Solar (\%) } \\
\text { Gas-Side Pressure Drop, CAT HILO (\%) } \\
\text { Gas-Side Pressure Drop, CAT DELP (\%) } \\
\text { Gas-Side Pressure Drop, 2D prediction (\%) }\end{array}$ & $\begin{array}{l}4.57 \\
4.57 \\
4.56 \\
6.00\end{array}$ & $\begin{array}{l}3.63 \\
3.63 \\
3.64 \\
4.70\end{array}$ & $\begin{array}{l}2.68 \\
2.60 \\
2.67 \\
3.30\end{array}$ & $\begin{array}{l}1.84 \\
1.84 \\
1.85 \\
2.20\end{array}$ \\
\hline
\end{tabular}

Four values of effectiveness are shown. The first value is based on the effectiveness calculated by Solar using the heat transfer rate on the air-side of the recuperator. The value is compared with the value of effectiveness calculated by the CAT data reduction analysis. These two values are generally in excellent agreement. The effectiveness based on the gas-side heat transfer rate is shown next. The difference between the air- and gas-side effectiveness values is due to the energy balance deviation, i.e., when the energy balance deviation is zero, the difference between the effectiveness calculated based on the air- and gas-sides of the recuperator vanishes. The effectiveness predicted by the $2 \mathrm{D}$ analytical method under the same operating conditions is also shown.

Similarly, the pressure drop on the air-and gas-sides of the recuperator are compared. Two values of pressure drop calculated by Cat Tech Center based on the differential pressure drop measurement (DELP) and measuring the absolute pressure values and subtracting the two (HILO) are also shown. The pressure drop values calculated by the 20 analytical method are shown as well.

The predicted and measured effectiveness and pressure drop values on the air-and gas-sides of the recuperator are compared in Figures 18 through 20 . The numbers shown in these figures refer to the test points identified in Tables 7-10. 


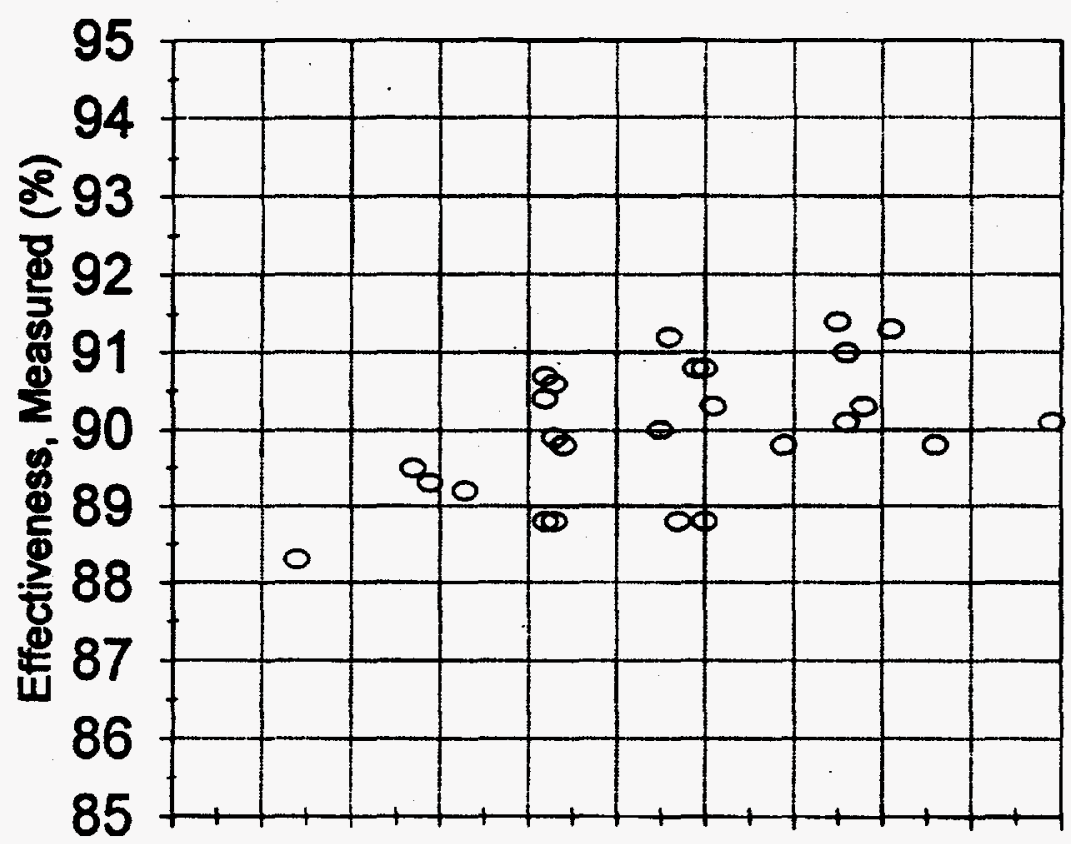

8586878889909192939495 Effectiveness, Predicted (\%)

Figure 18. Comparison Between Predicted and Measured Thermal Effectiveness

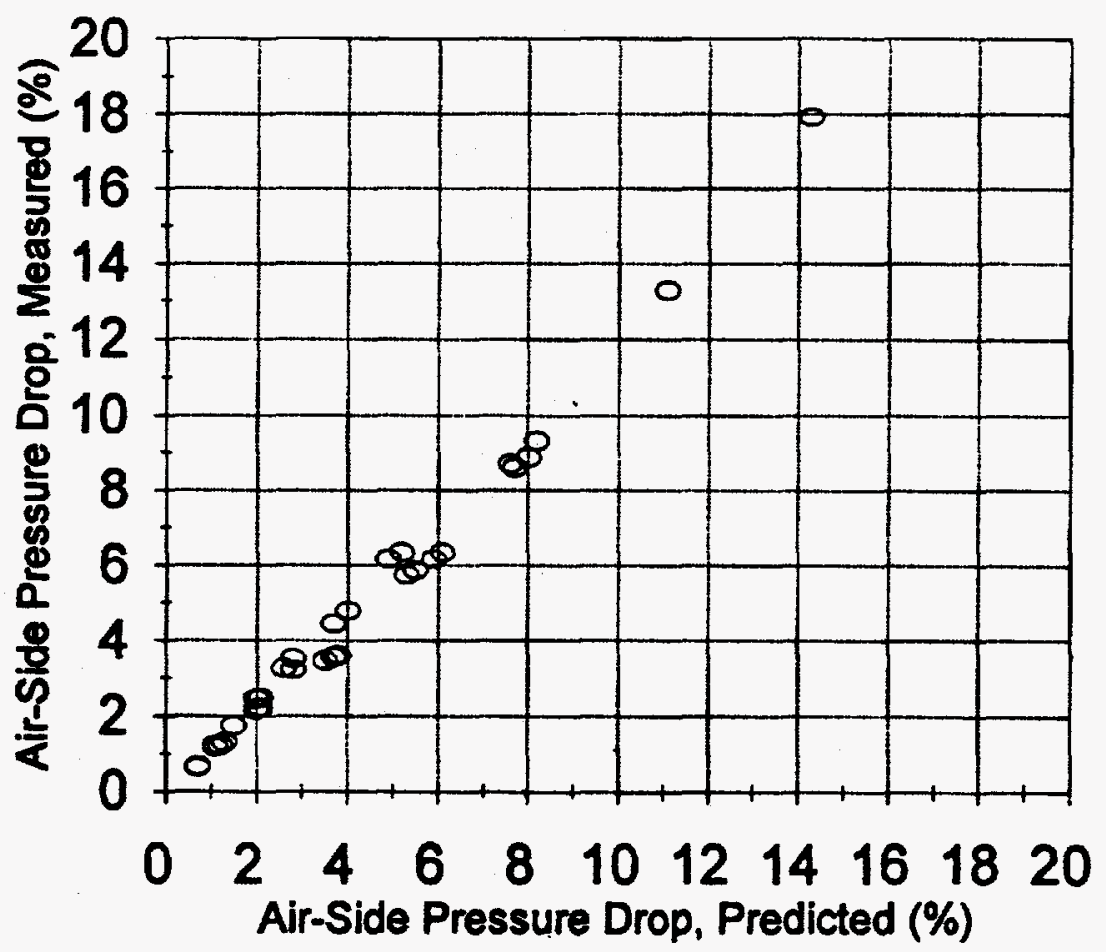

Figure 19. Comparison Between Predicted and Measured Air-Side Pressure Drop 


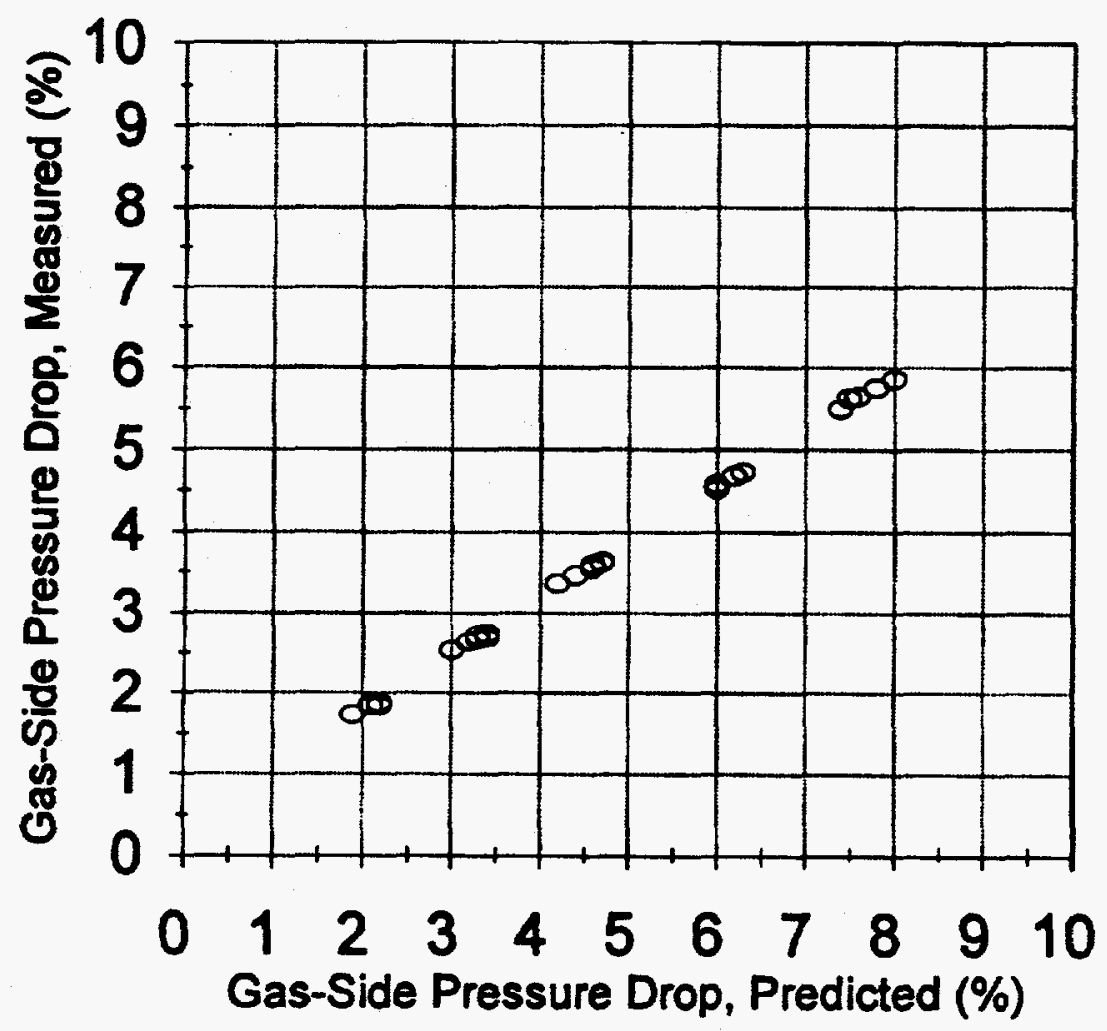

Figure 20. Comparison Between Predicted and Measured Gas-Side Pressure Drop

\subsection{FLATTENED TUBE TEST}

The Flattened Tube Test is still underway so it is premature to be discuss results at this time. A flattened tube of type 347 stainless steel has been running since late 1994. The high temperature strain gages have saturated so are no longer providing data. However, dimensional changes have been monitored every two weeks. From all indications, this data will be invaluable in validating finite element modelling of the primary heat transfer surface. 


\subsection{CONCLUSIONS}

\subsection{TRANSIENT TEST}

The addition of a thermal attenuator has resulted in minimizing the effects of thermal gradients in room air. This is expected to reduce the uncertainty of heat transfer surface performance data significantly. The rig was recommissioned successfully as evidenced by the reproducibility of standard surfaces $\# 19$ and $\# 52$.

Three primary surface cores were designed, manufactured and tested in the Transient Test rig. Pressure and temperature data were obtained for surfaces $\$ 90$ (high capacity, gas-side), \#91 (high capacity, air-side) and finally, \#92 (high capacity, combined). These data will fill the void with the needed empirical data that are necessary in the design, analysis and prediction of performance.

\subsection{PERFORMANCE TEST}

It is the conclusion of this report that all of these objectives of the test described in the previous section are satisfied. The comparison between pretest analytical prediction and test results shows good agreement between the two. The expected performance goals are met under both design-point and part-load conditions. The effectiveness values remained slightly higher than prediction under part-load conditions but the pressure drop on the air- and gas-sides of the recuperator is good over a broad range of conditions. The energy balance deviation improved significantly over previous tests due to rig modifications that addressed the issue.. However, the energy balance deviation could not be maintained under all test conditions within the 2-3\% limits due to leakage, heat loss, and measurement uncertainties, especially the uncertainties associated with the flow measurement and lack of relevant heat transfer performance data.

The performance goals were met at both design-point and part-load conditions. The thermal effectiveness was measured at $90.3 \%$ and the total pressure drop at $6.8 \%$ with a energy balance deviation of $1.4 \%$. Effectiveness values remained somewhat higher than predicted values under part-load conditions. The energy balance deviation and measurement uncertainties, factors such as leakage, heat loss and a lack of relevant heat transfer performance data can be key factors in the small differences between the predicted and measured effectiveness values.

\subsection{FLATTENED TUBE TEST}

It is difficult to state conclusions on this test as it is stil in progress. Nonetheless, a test rig was setup which includes a flattened tube having geometric similarity to the PSR folded profile. Dimensional changes have been monitored which will provide data to validate a finite element model of the creep behavior of the heat transfer surface. This will be useful in accurately predicting life. This test will continue until tube failure. 


\subsection{RECOMMENDATIONS}

\subsection{TRANSIENT TEST}

Some recommendations for future heat transfer performance testing and analysis of data just obtained are:

1. Manufacture and test additional test cores of the same three surfaces. This will tend to minimize the effects of manufacturing tolerances.

2. Manufacture additional combined surface cores from normal production runs to assess the effect of manufacturing variations, such as different folding blades, etc.

3. Incorporate the heat transfer performance data obtained in these tests into the 2D analytical model and assess any changes in the resulting predictions.

\subsection{PERFORMANCE TEST}

As a result of conducting the recuperator performance test, a number of recommendations for further work are stated:

1. An analysis of the conical headers, piping, and ducting needs to be undertaken in order to ensure that the flow distribution in the air cells is uniform and that the flangeto-flange pressure drop on the air- and gas-sides of the recuperator is within acceptable limits.

2. Recalibrate the $2 \mathrm{D}$ analytical method using the new surface performance data. This step should improve the accuracy of performance predictions.

3. Perform an uncertainty analysis of the steady-state rig to establish the uncertainties on the measured effectiveness and pressure drop values on the air-and gas-sides of the recuperator.

Steps 1 and 2 are intended to further increase the predictive accuracy of the 2D analytical model. The third step is intended to establish the degree to which the predicted results can be validated by experiment.

\subsection{FLATTENED TUBE TEST}

As this test is still in progress, it is difficult to make any long term recommendations. However, the data obtained will need to be used in conjunction with any finite element modeling. 


\title{
LIST OF ACRONYMS AND ABBREVIATIONS
}

\author{
ATS Advanced Turbine System \\ PSR Primary Surface Recuperator \\ TBRS Thermally balanced restraint system
}


three size fractions: particle diameters greater than $45 \mu \mathrm{m}$, particle diameters between $15 \mu \mathrm{m}$ and $45 \mu \mathrm{m}$, and ash particles with diameters less than $15 \mu \mathrm{m}$. (The sieving process caused this last, smallest fraction to be discarded along with the isopropanol used to wash the particles through the sieves with $45 \mu \mathrm{m}$ and $15 \mu \mathrm{m}$ openings.)

Table 1

Sieve Analyses of Tidd Ashes, \% wt.

\begin{tabular}{|l|c|c|c|}
\hline \multicolumn{1}{|c|}{ location, date } & diam $>45 \mu \mathrm{m}$ & $45 \mu \mathrm{m}>$ diam $>15 \mu \mathrm{m}$ & diam $<15 \mu \mathrm{m}$ \\
\hline \hline Tube sheet, Oct. 1994 & 4.03 & 17.3 & 78.6 \\
\hline Ash shed, Oct. 1994 & 0.64 & 3.84 & 95.5 \\
\hline Tube sheet, May 1995 & 28.9 & 50.7 & 20.4 \\
\hline Filter cake, May 1995 & 30.1 & 34.3 & 35.6 \\
\hline Tube sheet, May 1995 & 44.8 & 33.3 & 21.9 \\
\hline
\end{tabular}

In Figure 3, the size distribution data for these five samples obtained with the sieves have been combined with size distribution data obtained with a sedigraph. These data clearly show the increase in particle size induced by bypassing the cyclone.

The ash corresponding to the last row in Table 1 (tube sheet, May 1995) behaved much more like a free flowing powder than the other samples collected on the same site visit. This free flowing ash exhibited the largest particle size distribution of those ashes that were analyzed. When this ash was removed from the tube sheet, it was loose and fluffy, unlike the other ash samples that were consolidated into nodules and deposits. This type of difference is common with fine powders. Powders normally become more free flowing as their particle size distribution becomes coarser.

Chemical analyses of this free flowing ash and one of the nodular ashes were performed to determine if differences other than particle size might account for the tendency of the coarser ash to behave like a free flowing powder. Chemical analyses of these two ashes and the size-separated portions generated from them during sieving are summarized in Table 2. 


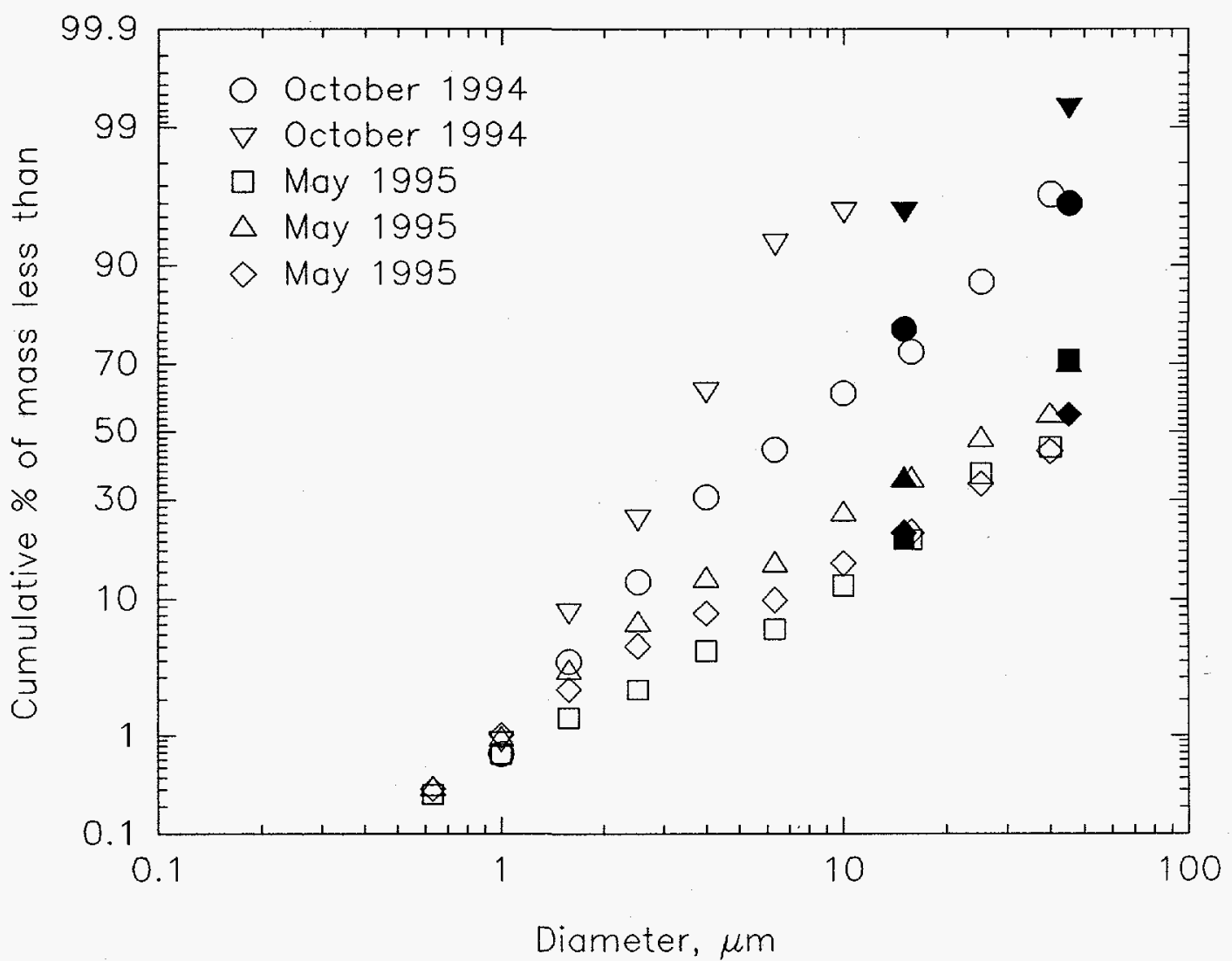

Figure 3. Cumulative size distribution data measured with a sedigraph and sieves for five ashes collected from the Tidd APF. The hollow data points represent sedigraphically obtained Stokes' diameters. The filled data points represent data obtained in the sieve analyses. 
Table 2

Chemical Analyses of Tidd Ashes Collected in May, 1995, \% wt.

\begin{tabular}{|l|c|c|c|c|c|c|}
\hline & \multicolumn{3}{|c|}{ fine, nodular ash (filter cake) } & \multicolumn{3}{c|}{ coarse, free flowing ash (tube sheet) } \\
\cline { 2 - 7 } constituent & all diameters & $\mathrm{d}>45 \mu \mathrm{m}$ & $\begin{array}{c}15 \mu \mathrm{m}<\mathrm{d}, \\
\mathrm{d}<45 \mu \mathrm{m}\end{array}$ & all diameters & $\mathrm{d}>45 \mu \mathrm{m}$ & $\begin{array}{c}15 \mu \mathrm{m}<\mathrm{d}, \\
\mathrm{d}<45 \mu \mathrm{m}\end{array}$ \\
\hline $\mathrm{Li}_{2} \mathrm{O}$ & 0.01 & 0.01 & 0.01 & 0.01 & 0.01 & 0.01 \\
\hline $\mathrm{Na}_{2} \mathrm{O}$ & 0.29 & 0.16 & 0.23 & 0.27 & 0.13 & 0.20 \\
\hline $\mathrm{K}_{2} \mathrm{O}$ & 1.3 & 0.83 & 1.3 & 1.2 & 0.77 & 1.1 \\
\hline $\mathrm{MgO}$ & 8.3 & 11.3 & 8.5 & 13.2 & 16.5 & 13.5 \\
\hline $\mathrm{CaO}$ & 14.1 & 18.1 & 15.0 & 20.5 & 24.7 & 21.0 \\
\hline $\mathrm{Fe}_{2} \mathrm{O}_{3}$ & 7.1 & 4.8 & 7.5 & 8.0 & 6.2 & 9.9 \\
\hline $\mathrm{Al}_{2} \mathrm{O}_{3}$ & 11.7 & 7.5 & 10.8 & 10.8 & 7.2 & 9.5 \\
\hline $\mathrm{SiO}_{2}$ & 26.1 & 17.6 & 26.0 & 25.1 & 19.6 & 25.6 \\
\hline $\mathrm{TiO}_{2}$ & 1.2 & 0.41 & 0.46 & 1.1 & 0.33 & 0.49 \\
\hline $\mathrm{P}_{2} \mathrm{O}_{5}$ & 0.15 & 0.12 & 0.14 & 0.14 & 0.10 & 0.14 \\
\hline $\mathrm{SO}_{3}$ & 30.1 & 38.5 & 28.5 & 19.5 & 22.9 & 17.4 \\
\hline $\mathrm{LOI}$ & 13.5 & 19.6 & 15.3 & 1.5 & 2.4 & 1.1 \\
\hline $\mathrm{Soluble} \mathrm{SO}_{4}{ }^{2}$ & 29.7 & 36.0 & 29.8 & 22.4 & 26.3 & 20.6 \\
\hline
\end{tabular}

Like other Tidd ashes we analyzed, the primary elemental constituents of these samples were calcium, magnesium, aluminum, silicon and sulfur. These analyses demonstrated that the larger ash particles in both samples contain more $\mathrm{Mg}, \mathrm{Ca}, \mathrm{SO}_{3}$, and have higher LOI values than the smaller particles. The smaller particles are richer in $\mathrm{Al}$, $\mathrm{Na}, \mathrm{K}, \mathrm{Fe}, \mathrm{Ti}$, and $\mathrm{Si}$. These results suggest that the larger ash particles are derived mainly from the sorbent used in the combustion process, while the smaller particles are derived mainly from the coal. This is supported by comparisons of the concentrations of calcium and magnesium in the two parent samples and their corresponding size fractions. The coarser tube sheet ash contains about $50 \%$ more calcium and magnesium than the finer filter cake ash. The particles too large to pass through the 45 $\mu \mathrm{m}$ sieve also had a different appearance than the finer particles. Whereas the finer particles all had the characteristic reddish-orange color associated with PFBC ashes, most of the larger particles were brown. A few of them were black or white. All of these differences suggest that the sorbent-derived ash particles were somewhat larger than the coal-derived ash particles in these samples. 